\title{
Late Pleistocene earthquake-triggered moraine dam failure and outburst of Lake Zurich, Switzerland
}

\author{
M. Strasser, ${ }^{1,2}$ C. Schindler, ${ }^{3}$ and F. S. Anselmetti ${ }^{4}$ \\ Received 22 March 2007; revised 29 August 2007; accepted 24 December 2007; published 9 April 2008.
}

[1] Lakes impounded by moraines may be considered hazardous in glaciated areas throughout the world because dams can fail suddenly producing destructive floods with peak discharges far in excess of normal flows. Here we present a comprehensive case study in the Zurich, Switzerland, area that reveals several independent lines of evidences for the occurrence of a Late Pleistocene ( 13,760 calibrated years B.P.) moraine breach and subsequent Lake Zurich outburst (discharge volume $\sim 2.5 \mathrm{~km}^{3}$ ). We use seismic and core data in order to track and date the geological fingerprint of this event. Data from areas downstream of the lake show coarse-grained massive ( $>25$ m thick) reworked morainic deposits behind four breached zones. In Lake Zurich, sedimentary structures recorded in a paleowater depth of $\sim 36 \mathrm{~m}$ indicate strong outburst-induced currents. Hydrodynamic calculations reconstructing the sediment transport capacity explaining the observed bed forms allow estimating averaged outburst discharge to exceed minimum values of $\sim 2400 \mathrm{~m}^{3} \mathrm{~s}^{-1}$. The potential maximal magnitude of the outburst is inferred from calculations considering critical flow conditions through the breaches revealing estimated peak discharge of $\sim 20,600 \mathrm{~m}^{3} \mathrm{~s}^{-1}$. We also discuss long-term causes and short-term trigger mechanisms of the dam failure that occurred several thousand years after moraine formation and show that it coincides with a reconstructed strong northern alpine earthquake (magnitude $>6.5$ ). Our data thus suggest that catastrophic drainage of Lake Zurich was initiated as a consequence of the moraine dam failure that either was triggered by primary earthquake shaking or by secondary effects, such as overtopping by landslide-generated waves.

Citation: Strasser, M., C. Schindler, and F. S. Anselmetti (2008), Late Pleistocene earthquake-triggered moraine dam failure and outburst of Lake Zurich, Switzerland, J. Geophys. Res., 113, F02003, doi:10.1029/2007JF000802.

\section{Introduction}

[2] Moraine-dammed lakes are common features in glaciated areas throughout the world. They are considered as a hazard to people and infrastructure in downstream areas because dams may fail suddenly producing destructive floods with peak discharges far in excess of normal flows [e.g., Costa and Schuster, 1988; Clague and Evans, 2000; Huggel et al., 2004]. Such lakes form during phases of glacial retreat behind moraine ridges deposited during an earlier advance. In alpine areas, still existing morainedammed lakes were formed after some glacial readvances and subsequent retreats during the Late Pleistocene, or much later, after the maximum advances of the Neoglacial (Little Ice Age) between the mid-19th and early 20th

\footnotetext{
${ }^{1}$ Geological Institute, Swiss Federal Institute of Technology Zurich, Zurich, Switzerland.

${ }^{2}$ Now at Research Center Ocean Margins, University of Bremen, Bremen, Germany.

${ }^{3}$ Retired.

${ }^{4}$ Sedimentology Group, Department of Surface Waters, Swiss Federal Instiute of Aquatic Science and Technology, Dubendorf, Switzerland.

Copyright 2008 by the American Geophysical Union. 0148-0227/08/2007JF000802
}

century. Scenarios for the future waning of glaciers in the context of global warming [e.g., Oerlemans, 2000] anticipate a significant increase in number and extent of potentially hazardous moraine-dammed proglacial lakes.

[3] Historically documented failures of moraine dams, subsequent lake outbursts and their geomorphic effects have been reported from numerous locations, including North America [O'Connor and Costa, 1993; Clague and Evans, 2000], the Himalayas [Watanabe and Rothacher, 1996], the Andes [Reynolds, 1992] and the European Alps [Huggel et al., 2002; Blass et al., 2003]. These studies have shown that such events can be caused by different mechanisms including (1) moraine dam overtopping by a wave or a series of waves generated by mass movements into or within the lake or by upstream glacial outbursts, (2) piping controlled by seepage in mostly silty and sandy diamictic deposits, (3) ice core or interstitial ice melting within the moraine wall during times of climatic warming, (4) earthquake shaking, or (5) combinations of above mentioned mechanisms (see review by Costa and Schuster [1988] and Clague and Evans [2000]).

[4] Considering longer geologic timescales, many studies document large prehistoric lake outburst floods that resulted from collapses of natural dams (not exclusively moraines 


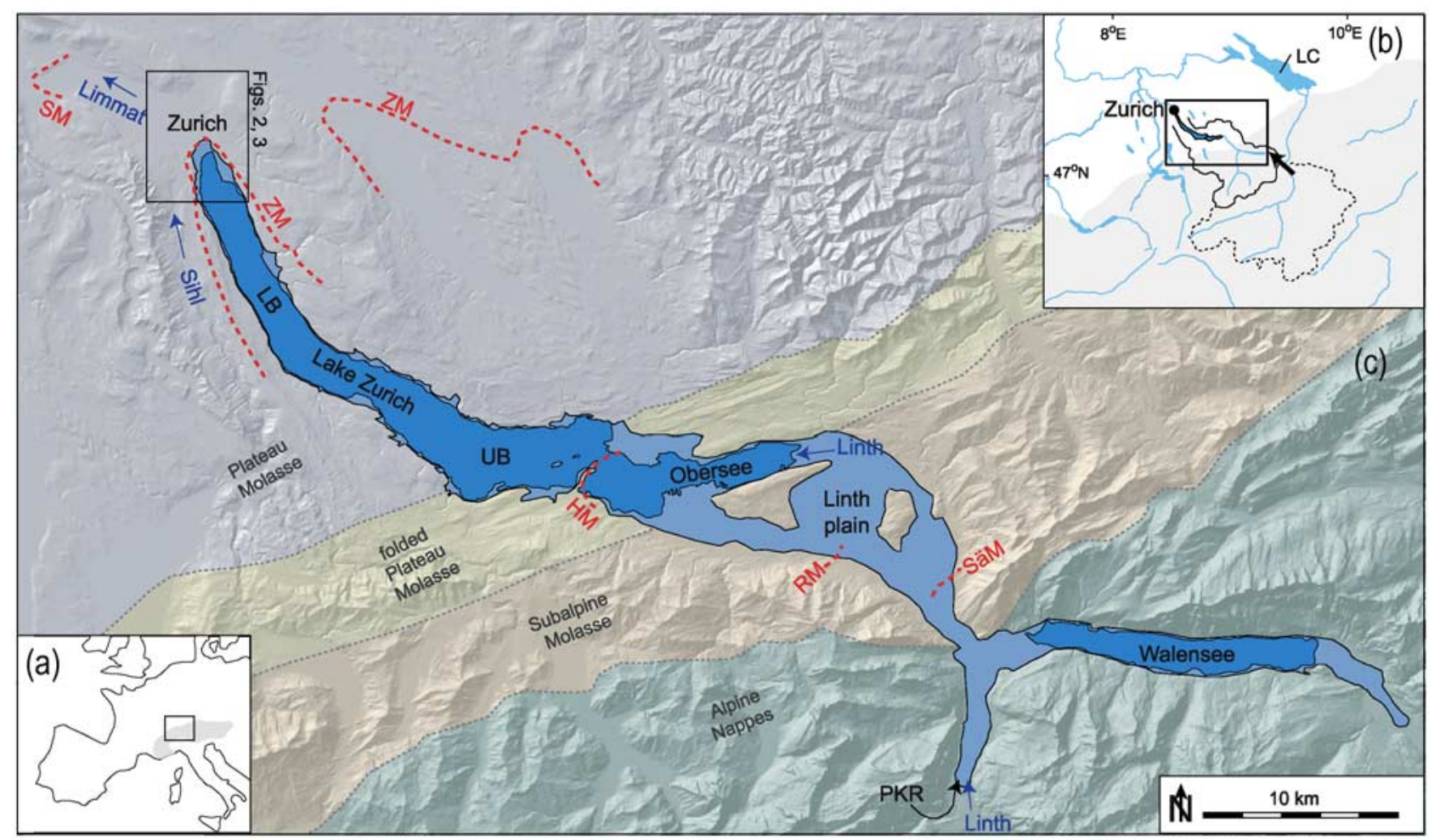

Figure 1. Geographic location of the study area embedded in its geomorphic and geological context. (a) The location with respect to Europe and the Alpine chain (gray-shaded area). (b) Close-up view showing the Alps (gray-shaded area) and the northern Swiss Plateau. The catchment area of Lake Zurich (Linth River) is mapped with a solid black line. Dashed line indicates additional glacial catchment area during the Last Glacial Maximum, when a branch of the Rhine Glacier coalesced with the Linth Glacier (indicated by black arrow). LC is Lake Constance. (c) Outlines of today's Lake Zurich (LB is lower basin and UB is upper basin), Obersee and Walensee (blue), and reconstructed extent (light blue) of the paleolake at $\sim 14,000$ calibrated years B.P. (see section 5.3). Blue arrows and annotations indicate flow direction and major rivers, respectively. Dashed red lines show prominent geomorphic features resulting from moraines that were formed during overall glacier retreat. From oldest to youngest: SM is Schlieren Moraine, ZM is Zurich Moraine, HM is Hurden Moraine, RM is Reichenburg Moraine, and SäM is Schänis Moraine. Black arrow (PKR) marks location of Planggen-Klöntal rockslide [Schindler, 2004]. Shaded relief of digital elevation model (dhm25, Swisstopo) overlain by the general tectonic setting. Rectangle in the northwestern part of Figure 1c indicates location of Figures 2 and 3.

but also landslide, ice, and others dams [e.g., Rudoy, 2002; Schneider et al., 2004; Carter et al., 2006] (see general considerations by Costa and Schuster [1988]). Especially in Late Pleistocene and Early Holocene times very large outburst floods occurred during the destabilization of large continental ice sheets after the Last Glacial Maximum (LGM). They include the "Spokane flood" from Lake Missoula [O'Connor and Baker, 1992], Lake Agassiz paleofloods [Smith and Fisher, 1993] and Lake Bonneville flood [Malde, 1968]. Theses floods are generally interpreted to have had significant impact on landscape evolution in downstream areas, for instance in the context of formation of outburst gorges and changes in river routing systems [e.g., Teller and Thorleifson, 1983; Rudoy, 2002]). Furthermore, they potentially could have triggered short-term climatic excursions due to the large fresh water input into the ocean that temporarily affected the thermohaline circulation pattern [Clarke et al., 2004; Broecker, 2006]. Whereas most of these documented megafloods are related to ice-dam collapses draining both supraglacial and/or subgla- cial lakes, detailed case studies on processes, causes and consequences of Late Pleistocene postglacial lake outbursts resulting from moraine-dam failures are rare. Such geologic information is crucial in order to assess the hazard potential of future events, especially in the context of present-day climatic warming and rapid glacier retreat, during which the formation rate of potentially hazardous moraine-dammed lakes is increasing.

[5] Here we present results from a detailed case study in the Zurich area (central Switzerland, Figure 1) that aims to reconstruct a Late Pleistocene moraine-dam failure and subsequent lake outburst. Occurrence of such an event has been hypothesized by Schindler [1971], but has so far lacked conclusive interpretation of trigger mechanism, accurate timing and consequences. Our new geophysical, sedimentological and geomorphological data of Lake $\mathrm{Zu}-$ rich sediments and of downstream deposits combined with hydrodynamic calculations allow us to reliably support and refine Schindler's [1971] outburst hypothesis and to discuss 
in detail long-term causes and short-term trigger mechanism(s) and their impact as recorded in geological archives.

\section{Geological/Geomorphological Background}

\subsection{Regional Setting}

[6] The Linthplain Lake Zurich-Limmat valley occupies a perialpine, glacially overdeepened, NW-SE trending trough situated in the northern part of the Swiss Plateau (Figure 1). During the last glacial period it was fully occupied by two coalesced alpine glaciers (Linth Glacier and a branch of the Rhine Glacier; Figure 1b) with a maximum extent during the LGM reaching $\sim 20 \mathrm{~km}$ downstream of today's city of Zurich. During deglaciation, intermediate phases of stagnation and minor glacial readvances resulted in a succession of recessional moraines separating several basins and damming proglacial lakes [Penk and Brückner, 1909; von Moos, 1942; Schindler, 1968, 1974, 2004]. The most prominent ice-marginal stages are from NW to SE (from oldest to youngest) (1) Schlieren Moraine (SM) damming the former Schlieren Lake, (2) Zurich Moraine (ZM) damming Lake Zurich, (3) Hurden Moraine (HM) separating Lake Zurich from Obersee, (4) Reichenburg Moraine (RM), and (5) Schänis Moraine (SäM) (Figure 1). In early Late Glacial times immediately after the glacial retreat back into the alpine valleys, an extended paleolake combining today's Lake Zurich, Walensee and probably also Lake Constance [Müller, 1995] occupied most of the formerly glaciated area. This paleolake was dammed by the Zurich Moraine at a lake level of $416-418 \mathrm{~m}$ above sea level (masl) that was significantly higher than today's Lake Zurich level (406 masl). This is indicated by elevated glaciolacustrine deposits along the shorelines and higher levels of proglacial delta deposits in the vicinity of the Hurden, Reichenburg, and Schänis moraines [Schindler, 1971, 2004]. The altitude level of these delta deposits allowed for absolute paleolake level reconstruction after correcting for differential surface uplift between the Zurich and Walensee area (measured uplift rates today, are $\sim 0.1$ and $0.6 \mathrm{~mm} / \mathrm{a}$ (where a is years), respectively [Kahle et al., 1997]). Constant altitude levels of paleodelta deposits in the whole study area indicate that a general lake level highstand prevailed during all recessional deglaciation phases after the glacier retreated from the lower Lake Zurich basin at $\sim 17,600$ calibrated years B.P. (Lister [1988] calibrated using InterCal04 calibration curve by Reimer et al. [2004]).

[7] In the eastern part of the study area, the paleolake size successively was reduced by the progradation of the Linth delta (Figure 1). This resulted in the separation between Lake Zurich and Walensee $\sim 11,500$ calibrated years B.P and in the infilling of the Linthplain during Holocene times [Schindler, 2004]. Paleolake level since $\sim$ Bølling/Allerød and throughout Holocene times, as reconstructed from altitude information of delta deposits, shore terraces and lake shore dwellings, respectively, was significantly lower than the 416-418 masl during the deglaciation phase. These lower lake levels only slightly oscillated between minimum 403 and maximum 407 masl corresponding to climatic variations, precipitation pattern and Sihl River sediment discharge that partially may have influenced the Limmat River outflow situation [Schindler, 1971; Magny, 2004; Riesen and Naef, 2007].

\subsection{City of Zurich Area}

[8] In the Zurich area, the Zurich Moraine (maximal age $\sim 23,700$ calibrated years B.P (Schlüchter and Röthlisberger [1995] calibrated using InterCal04 calibration curve by Reimer et al. [2004])) reaches a height of $\sim 20 \mathrm{~m}$ above the present valley floor. The moraine wall itself is composed of up to three amalgamated structurally complex frontal recessional moraines (Figure 2a). They are partly covered with basal tills from a glacier oscillating back and forth several times during the Zurich Stage [Schindler, 1968]. In the north the Schlieren Lake (estimated paleolake level $\sim 405$ masl [Schindler, 1968]) initially occupied most of the Limmat valley. High-sediment supply from the Sihl River and subsequent Sihl delta progradation continuously reduced the size of the Schlieren Lake so that since early Holocene times the basin has been completely filled (Figure 2b).

[9] Today, there are only isolated remnant hills from the frontal part of the Zurich Moraine, which are separated from each other by four $\sim 200$ to 400 -m-wide eroded zones (Figure $2 b$ ). In all of these four areas data from drill cores and open constructions pits reveal the top of the indurated moraine deposits to be systematically at a similar topographic level of 402-405 masl. These moraine surfaces occur below $\sim 4-7 \mathrm{~m}$ of alluvial, lacustrine and artificial infill deposits [e.g., Schindler, 1968, 1971; Jäckli, 1989, and references therein]. This indicates that at these locations the uppermost $\sim 20-30 \mathrm{~m}$ of the moraine dam has been eroded sometimes in the past and that the breaches afterward have been infilled to the present-day level. Several studies [e.g., Huber, 1938; Jäckli, 1989] have reported that the Sihl River temporarily discharged into Lake Zurich backward through the eroded breaches as indicated by Sihl delta deposits accumulated in Lake Zurich during Bølling/Allerød to Early Holocene times.

\subsection{Moraine Breach Hypothesis}

[10] Because of the fact that the level of Lake Zurich was initially higher than the base level of the Sihl River (Figure 2a), and because of observations that all four proposed breach locations are eroded down to a similar topographic level (402-405 masl), Schindler [1971] postulated that the erosion of the moraine wall was mainly caused by an instantaneous moraine failure sometime during Late Glacial times. As a consequence, the level of Lake Zurich must have been lowered within a very short time by $\sim 12 \mathrm{~m}$ (i.e., the difference between paleolake level and lake level at the beginning of Sihl delta sedimentation in Lake Zurich). Schindler's [1971] hypothesis was partly supported by observations from drill cores and open construction pits immediately north of the former moraine wall that showed thick reworked morainic deposits (hereafter termed RM deposits) intercalated between normally consolidated lake sediments assigned to the Schlieren Lake below, and alluvial gravels assigned to the Sihl fan and Limmat River above.

[11] Since the early 1970s, however, only very few studies tested this hypothesis [Furger, 1991; Schindler, 2004], and it has not been shown so far whether these RM deposits conclusively reveal the occurrence of a moraine-dam failure and subsequent lake outburst. Furthermore, the effects that such an event would have had on Lake 

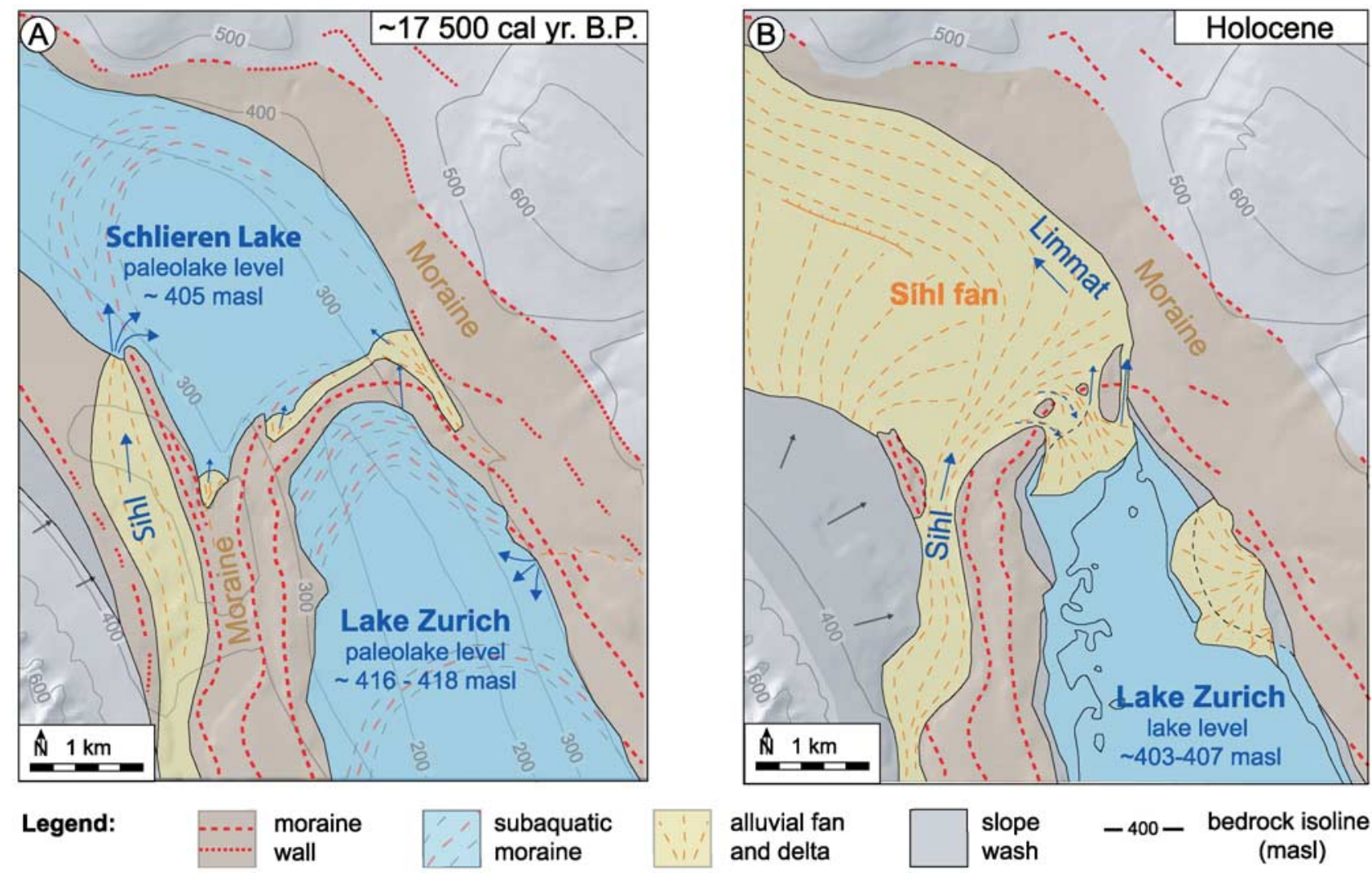

Figure 2. Maps showing the reconstructed geomorphologic situation in the area of the city of Zurich based on unpublished reports and core information from geoconsulting companies Jäckli AG, Geo Von Moos AG, and Sieber \& Cassina (2006) and publications by Schindler [1968], Kempf et al. [1986], and Jäckli [1989]. (a) The situation during early Late Glacial times after the Linth Glacier left the Lake Zurich basin $(\sim 17,500$ calibrated years B.P). (b) The situation during Holocene times. Shaded relief of digital elevation model (dhm25, Swisstopo) and isohypse of molassic bedrock after Jäckli [1989].

Zurich and on downstream parts of the Limmat valley, as well as the exact timing and triggering mechanism, remain unknown.

\subsection{Lake Zurich}

[12] Lake Zurich can be divided into two basins (1) a northwestern, elongated deep basin (max depth $135 \mathrm{~m}$ ) with steep lateral slopes and a flat basin plain, and (2) a flat and shallow ( $\sim 20$ m water depth) upper basin, which is separated from the lower basin by a subaqueous rock barrier showing a complex, step-like morphology descending toward the NW [Hsü and Kelts, 1970; Schindler, 1976]. A mostly sub aerial sill formed by the Hurden Moraine with only $2 \mathrm{~m}$ deep lake passages separates Lake Zurich from Obersee in the E.

[13] Several previous studies in the 1970s and 1980s described Lake Zurich's geology and its sedimentary and environmental evolution since the LGM [Hsü and Kelts, 1970, 1984; Schindler, 1974, 1976; Kelts, 1978; Giovanoli, 1979; Pika, 1983; Lister, 1985, 1988; Sidler, 1988]. These studies are mainly based on data from the deep northwestern basin comprising some seismic lines and piston cores, and one deep drill hole termed "Zübo" [see Hsü and Kelts, 1984, and references therein]. These data reveal that in the lower Lake Zurich basin, the molasse bedrock is covered with an up to $140 \mathrm{~m}$ thick, mainly glacial and glaciolacus- trine infill. The majority of these sediments were accumulated in a subglacial environment. Only the uppermost $\sim 30 \mathrm{~m}$ were deposited after the glacier retreated from the lower Lake Zurich basin (see lithostratigraphical description in section 4.2.2). In this upper sedimentary succession, none of the previous studies specifically addressed the correlation of characteristic event layers throughout the lake in order to test the moraine-dam failure and lake outburst hypothesis.

\section{Methods}

[14] With the objective to identify and date traces of the proposed lake outburst, we refined the existing sedimentary model of the postglacial infill of the lower Lake Zurich basin and extended it to the upper basin by acquiring new high-resolution seismic reflection data and four new long sediment piston cores. A dense grid of $\sim 300 \mathrm{~km}$ of single channel $3.5 \mathrm{kHz}$ seismic profiles (pinger source) was acquired and allowed for imaging the subsurface in a quasi three-dimensional (3-D) fashion. The source/receiver was mounted on a cataraft that was pushed in front of a small vessel. DGPS positioning with a maximum error of $\pm 2 \mathrm{~m}$ guaranteed accurate navigation. The digitally recorded data were processed using both a flat gain and band-pass filtering. Two-way travel time was converted to water depth 
and sediment thickness using a constant velocity of $1450 \mathrm{~ms}^{-1}$.

[15] Four Kullenberg-type gravity piston cores [Kelts et al., 1986], each $8-10 \mathrm{~m}$ in length, were recovered at key positions identified in the seismic data to ground truth the seismic data, for detailed sedimentological analyses and dating. The cores were scanned with a GEOTEK multisensor core logger, which measures bulk density by gamma ray attenuation, $\mathrm{P}$ wave velocity and volumetric low field magnetic susceptibility. Afterward, cores were split, photographed and sedimentologically described. One core section that recorded a conspicuous sedimentary succession was imaged with a medical fluoroscope $\mathrm{X}$ ray instrument in order to visualize sedimentary structures that were not visible in the cores macroscopically. The same distinctive interval was analyzed for grain size distribution of bulk sediment using laser diffraction techniques (Malvern Mastersizer Hydro 2000S) at $\sim 0.5 \mathrm{~cm}$ intervals along the split core. Accelerator mass spectrometry ${ }^{14} \mathrm{C}$ analysis on terrestrial organic matter (mainly leaf fragments) sampled at different stratigraphic levels in three cores were performed at the Particle Physics Laboratory of ETH Zurich to date the sedimentary succession. Radiocarbon ${ }^{14} \mathrm{C}$ ages were calibrated using the InterCal04 calibration curve [Reimer et al., 2004]. Noncalibrated ages given in previous studies were also calibrated [Reimer et al., 2004], so that all ages in this study refer to the same timescale.

[16] In order to evaluate whether the described RM deposits [Schindler, 1971] downstream of the Zurich Moraine can be related to the proposed moraine-dam failure, published as well as unpublished core information from the Zurich City area were collected and compiled [Kempf and Walter, 1985; Kempf et al., 1986] (Tables S1a-S1c). ${ }^{1}$ Here, we only considered interpreted log information from cores reaching deep enough to clearly identify the RM facies (see section 4.1). Visual spatial core-to-core correlation then allowed reconstructing the relative stratigraphic position, extent and distribution of thickness of these target deposits.

\section{Data and Results}

\subsection{Reworked Morainic Deposits}

[17] Several boreholes drilled in the urban area of Zurich during the last $\sim 40$ years recovered a characteristic lithological unit composed of massive diamictic deposits containing subangular, sometimes striated cobbles and boulders, suggesting a glacial origin or glacial deposits as source material [Kempf and Walter, 1985; Kempf et al., 1986] (Tables S1a-S1c). This unit is normally consolidated and overlies either laminated lacustrine silt and fine sand or well-sorted alluvial sand and gravel deposits that also are normally consolidated and lack any evidences of being formed or affected by glacial processes. In core logs, the diamictic deposits were described and interpreted as "moränenartig" (morainic), "verschwemmte Moräne" (flushed till deposits), "verschleppte Moräne" (remobilized till deposits), or "moränenartige Murgang Ablagerungen" (morainic debris flow deposits). From its sedimentary facies,

\footnotetext{
${ }^{1}$ Auxiliary materials are available in the HTML. doi:10.1029/ 2007JF000802.
}

absent evidence of glacial compaction and its peculiar stratigraphic position within a normally consolidated postglacial sedimentary succession, these deposits (here summarized as RM deposits) are interpreted to indicate a postglacial remobilization of moraine material.

[18] Systematic mapping of thickness, stratigraphic position and elevation of the RM deposits base and top reveal distinctive spatial depositional features (Figure 3). In the western moraine-proximal part, the deposits form two small well-pronounced lobes with maximum thickness of $\sim 15$ to $20 \mathrm{~m}$ at their apex points that coincide with the positions of two eroded breach locations through the Zurich Moraine. These two lobes have a length of $\sim 200$ to $600 \mathrm{~m}$. Their stratigraphic position implies that they were deposited above Sihl fan deposits with a contact at an elevation level of $\sim 395$ to 400 masl. In the eastern proximal part, the RM deposits are up to $30 \mathrm{~m}$ thick and stratigraphically overly mostly proglacial lake deposits at $\sim 370$ to 380 masl. Only in the easternmost part the unit is thinner and overlies alluvial fan deposits assigned to a small local creek draining the eastern flank of the Limmat valley (Wolfbach; Figure 3) at $\sim 395$ masl. At $\sim 3 \mathrm{~km}$ distance from the Zurich Moraine the unit is $5-10 \mathrm{~m}$ thick, and a fining and thinning toward more distal parts can be observed in the bore log data. Further downstream, core logs lack any descriptions of the RM facies but a conspicuous, up to 5-m-thick sand layer was recovered at the stratigraphic position between the lacustrine sediments of Schlieren Lake below and coarse alluvial deposits assigned to the Limmat River above.

\subsection{Lake Zurich Data}

\subsubsection{Seismic Stratigraphy}

[19] Seismic penetration of the $3.5 \mathrm{kHz}$ signal amounts to $\sim 50$ and $\sim 75 \mathrm{~ms}$, corresponding to $\sim 35$ and $\sim 60 \mathrm{~m}$ in the lower and upper basin, respectively (Figure 4). The imaged succession can be divided into two main seismostratigraphic units.

[20] 1. The lower seismic Unit A comprises a thick $(\sim 15$ to $25 \mathrm{~m}$ and up to $55 \mathrm{~m}$ in the lower and upper basin, respectively) succession of acoustically stratified sediments characterized by parallel, widely spaced reflections showing alternating high and low seismic amplitudes. Toward the basin margins, these reflections are more closely spaced and often onlap onto the acoustic basement, indicating a dominant ponding style of sedimentation.

[21] 2. The upper seismic Unit $B(\sim 5-7 \mathrm{~m}$ thick $)$ is characterized by closely spaced, parallel reflections (medium-to-high and low-to-medium amplitudes in the lower and the upper basin, respectively). Unit B forms a drape across the entire basin, which also generally covers the steep slopes and the bedrock high.

[22] In the deep basin the two seismic units are separated by a thin package ( 0.5 to $1 \mathrm{~m}$ thick) of coherent, highamplitude reflections. Sedimentary bodies with a horizontal extent of a few 10 s to 100 s of meters with internal chaoticto-transparent seismic facies and clear lateral pinch-out geometries can be identified throughout the sedimentary succession. They indicate that slumping and landsliding along the relatively steep lateral slopes occasionally punctuated the otherwise continuous postglacial sedimentation in Lake Zurich. 


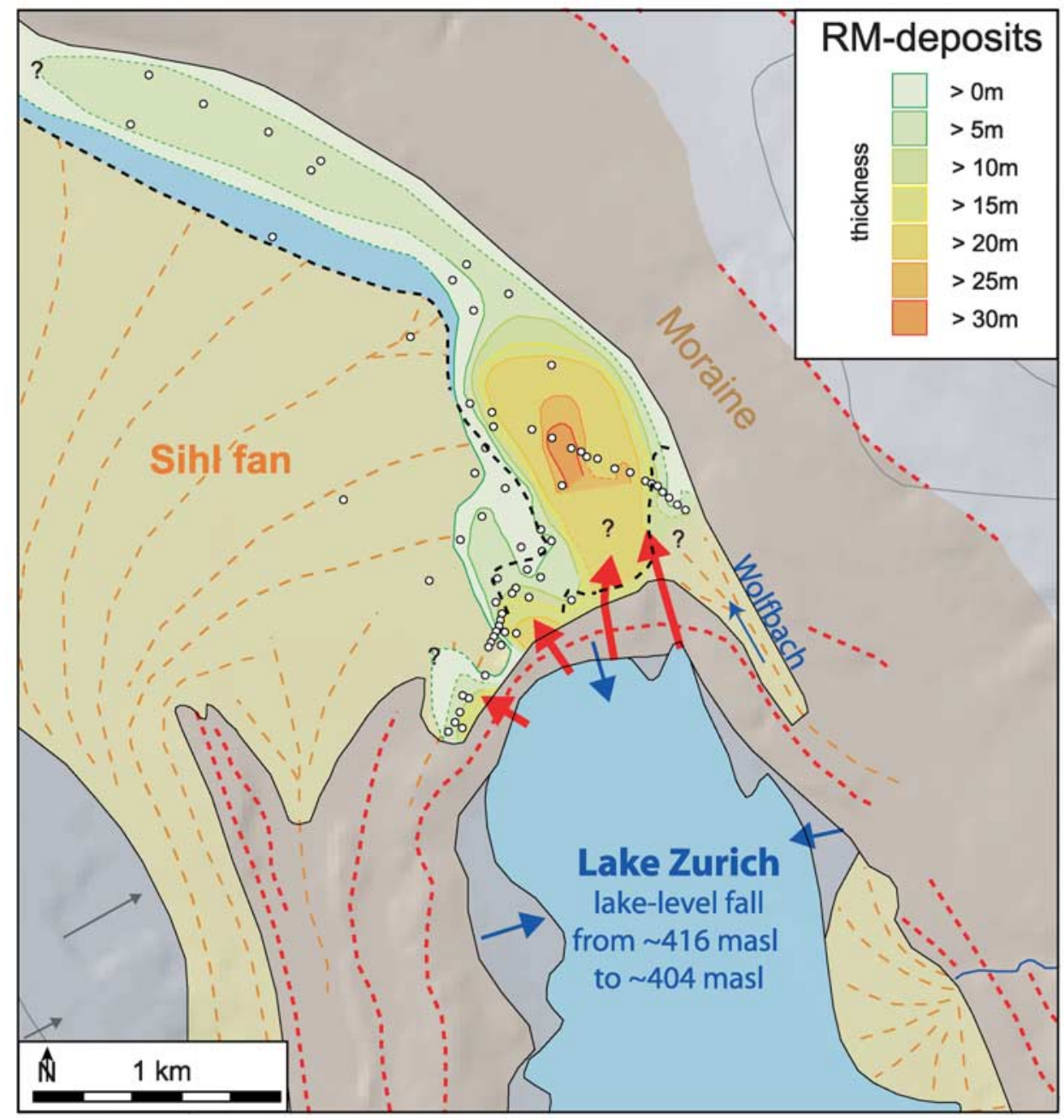

Figure 3. Map showing reconstructed thickness distribution of reworked morainic deposits (RM deposits). The reconstruction is based on core logs from unpublished reports and core information from geoconsulting companies Jäckli AG, Geo Von Moos AG, and Sieber \& Cassina [2006] and publications by Kempf and Walter [1985] and Kempf et al. [1986]. Open circles indicate locations where core information was available. Question marks indicate areas where data coverage was not sufficient enough to reconstruct exact extent and thickness of the RM deposits. Red arrows indicate positions of four breaches eroded through the frontal ring of the Zurich Moraine. Black dashed lines indicate boundaries between areas, where the RM deposits stratigraphically overlay Sihl fan (western part), Schlieren Lakes deposits (central part), and local alluvial fan deposits (eastern part), respectively.

\subsubsection{Lithostratigraphy}

[23] All four acquired sediment cores recovered the characteristic postglacial stratigraphic succession that reflects the sedimentary and environmental evolution of Lake Zurich as already described in previous studies from cores in the central part of the deep basin [Giovanoli, 1979; Hsü and Kelts, 1984; Kelts, 1978; Lister, 1985; Pika, 1983; Sidler, 1988]. Figure 5 shows a compilation of available core information and physical property data from Lake Zurich along the longitudinal lake axis. The general sedimentary succession comprises three lithologic units (from bottom to top).

\subsubsection{Lithologic Unit 1 ("Glaziale Seebodenlehme": Plastic Mud)}

[24] Sticky, medium-gray, plastic clays to silty clays with high bulk densities showing distinct up to 5-cm-thick laminations in the lower part (laminated plastic mud); thin $\mathrm{mm}$-scale laminations intercalated with yellowish, mmscale silt to fine sand layers in the middle part (faintly laminated plastic mud); and homogenous to mottled textures in the upper part (mottled plastic mud). This lithologic unit corresponds to the lower seismic Unit A described above. Thicker clastic laminae in deep water cores contrast thinner laminae in shallow water cores and thus confirm the ponding depositional style of this sedimentary unit. The lithology and infill pattern indicate glaciolacustrine sedimentation by underflows in a proglacial environment [Kelts, 1978; Hsü and Kelts, 1984; Lister, 1985].

\subsubsection{Lithologic Unit 2 ("Basaler Faulschlamm": Iron Sulfide Mud)}

[25] Dark greenish-gray, fine-grained mud with low carbonate content and low bulk densities showing a distinct 


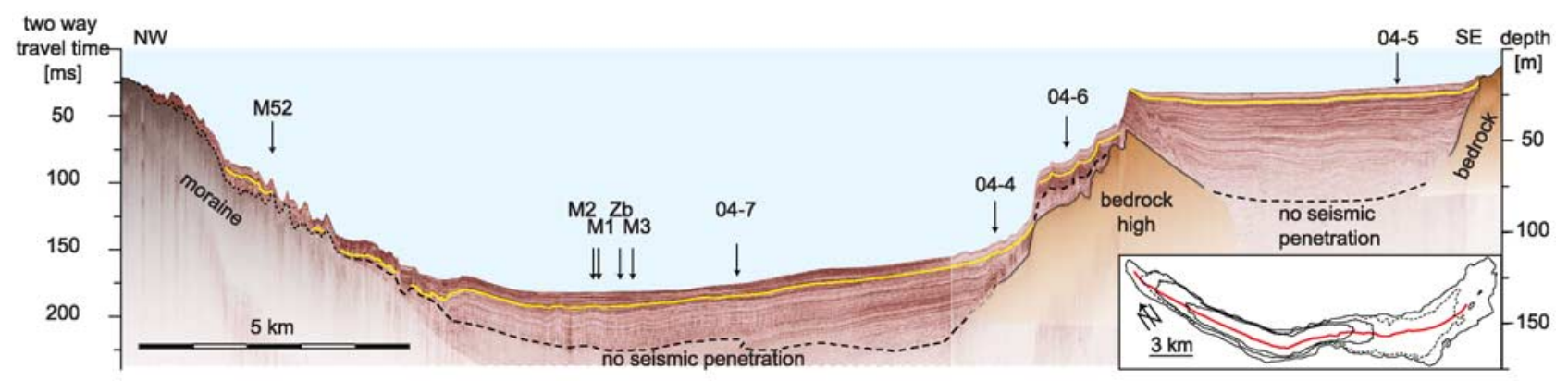

Figure 4. The $3.5 \mathrm{kHz}$ reflection seismic profile (pinger source) imaging the subsurface of Lake Zurich along the whole longitudinal lake axis and locations of cores shown in Figure 5. Yellow line in the seismic data marks the characteristic E layer showing multiple mass movement deposits (Figures 7a and 7b) and wavy seismic features (Figure 7d) in the lower deep and upper flat basin, respectively. It also corresponds approximately to the boundary between seismostratigraphic Unit A below and Unit B above. Inlet in the lower right corner shows location of the seismic line (solid red line). Contour interval is $50 \mathrm{~m}$. Dotted contour line marks 20-m-depth contour line and aims to clarify basin morphology in the upper flat basin.

appearance of several highly FeS-pigmented black laminations and intercalated $\mathrm{cm}$ thick sandy and muddy turbidites. From its stratigraphic position, this unit corresponds to the seismic high-amplitude reflections in the transition zone between seismic Units A and B. It is interpreted that, with postglacial climatic amelioration and the final retreat of the glaciers back into the Alps, sediment supply into the lake was reduced and the lake became stratified. Lacustrine biota increased and oxygen content in the bottom water dropped occasionally to anoxic levels, resulting in characteristic FeSpigmented black laminations of the lithological unit [Kelts, 1978; Pika, 1983].

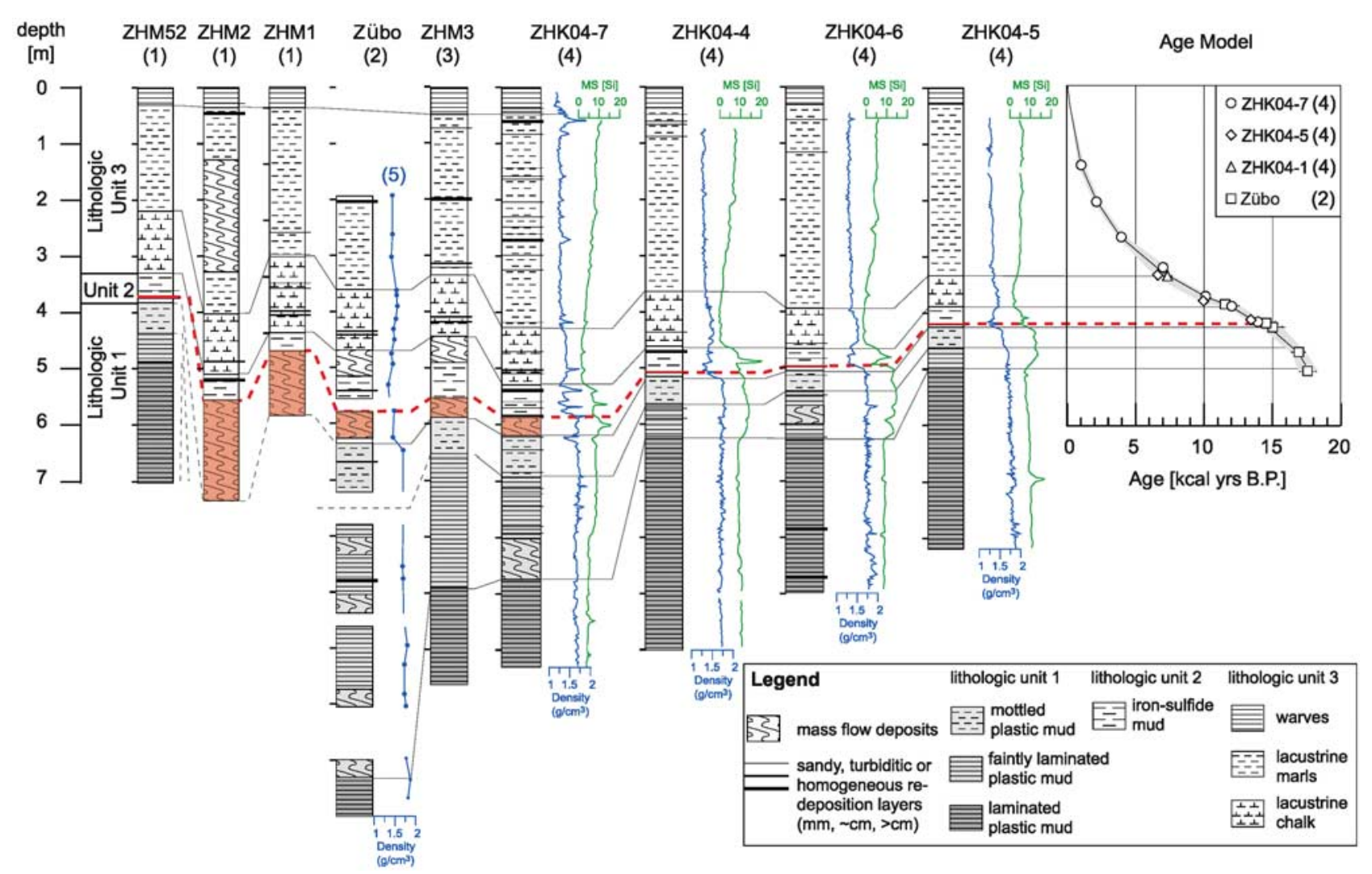

Figure 5. Core transect compiling available core information and physical property data from Lake Zurich along the longitudinal lake axis ((1) Giovanoli [1979], (2) Lister [1988], (3) Pika [1983], (4) this study, and (5) bulk density data by Eberli [1984]) and age model of the composite stratigraphic section. See Figure 4 for core locations. Red colored deposits and dashed line show the E layer mass movement deposits and core-to-core correlation, respectively. 
Table 1. Dating of Outburst Event

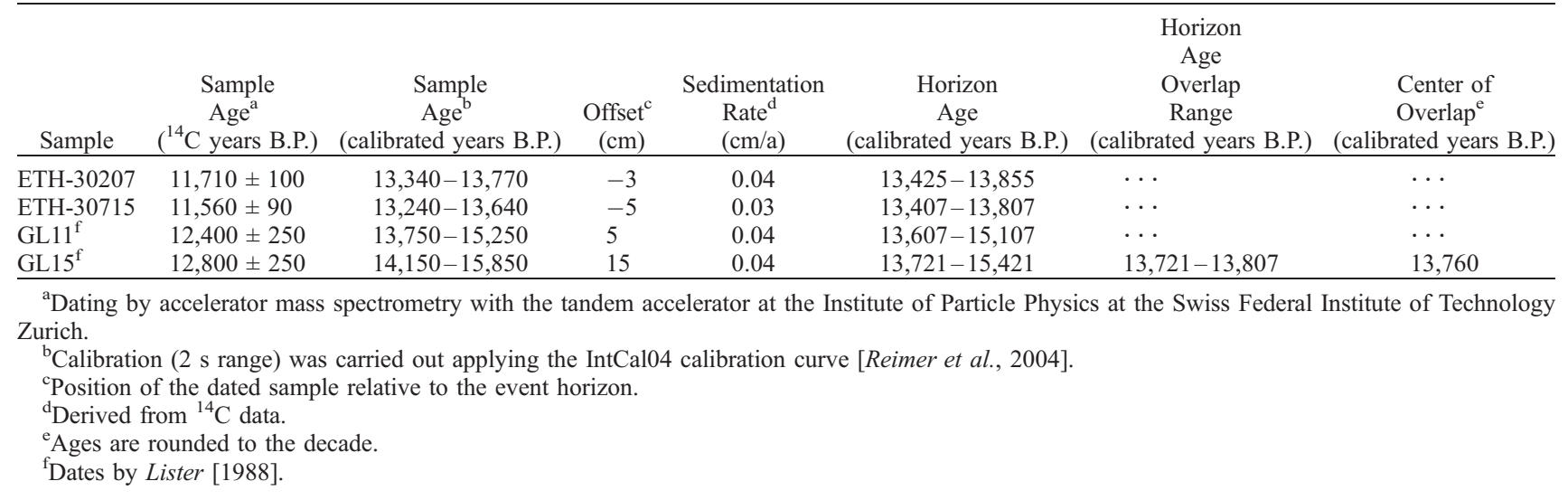

\subsubsection{Lithologic Unit 3 ("Seekreide" and "Seekreide- Mergel": Lacustrine Chalk and Marls)}

[26] Light gray (lower part) to greenish gray (upper part), faintly layered lacustrine chalk (lower part) and marls (upper part) composed of terrigenous mud rich in authigenic carbonate, intercalated with $\mathrm{cm}$ thick sandy and muddy turbidites. These deposits correspond to the upper seismic Unit B and were deposited when bioinduced calcite precipitation and minor clastic input from small local creeks were the dominant sediment sources in the mesotrophic holomictic lake. The uppermost $50-70 \mathrm{~cm}$ show distinct rhythmically layered calcite/organic couplets (varves) representing sedimentation during the last $\sim 100$ years of human-induced lake eutrophication [Kelts, 1978; Pika, 1983].

[27] Sixteen ${ }^{14} \mathrm{C}$ ages derived from samples in four different cores (Table S2) provide a high-resolution age control for the cored sedimentary succession. The resulting age model of the composite stratigraphic section (Figure 5) reveals Holocene ages for the lithologic Unit 3 (seismic Unit B), Younger Dryas to Bølling ages for lithologic Unit 2 and Oldest Dryas and older ages for the lower lithologic Unit 1 (seismic Unit A).

\subsubsection{An Outstanding Event Layer}

[28] The newly acquired basin-wide quasi 3-D stratigraphy allows identifying a conspicuous event layer that was recorded throughout Lake Zurich (hereafter termed E layer). It occurs in the lowermost part of lithologic Unit 2, a few $\mathrm{cm}$ above the boundary to the underlying Unit 1 and is dated to $13,760 \pm 45$ calibrated years B.P. (i.e., overlap age of independently dated ages in three different cores, Table 1). In all cores (including shallow water cores ZHM52 and ZHK04-5) this E layer is characterized by the occurrence of a prominent $1-5-\mathrm{cm}$-thick turbidite or by 0.5-2-m-thick mass-flow deposits (Figure 5). In the seismic data the $\mathrm{E}$ layer corresponds to a distinct seismostratigraphic horizon at the base of the transition zone between seismic Units A and B. Along this horizon, a total of 23 individual mass movement bodies with internal chaotic-to-transparent seismic facies and clear lateral pinch-out geometries have been mapped in the seismic data all over Lake Zurich (Figures 6, 7a, and 7b; see Schnellmann et al. [2006] and Strasser and Anselmetti [2008] for detailed description of the used seismic stratigraphic mapping procedure). The occurrence of multiple mass movement deposits within one isochronous seismostratigraphic horizon suggests si- multaneous landsliding throughout the lake and implies a regional trigger mechanism for mass movement initiation, such as earthquake shaking or lake level change [cf. Shilts and Clague, 1992; Hampton et al., 1996; Schnellmann et al., 2002].

[29] In the upper basin the E layer seismically stands out as a remarkably high-amplitude reflection in $\sim 4 \mathrm{~m}$ depth (Figures $7 \mathrm{c}$ and $7 \mathrm{~d}$ ). This reflection is immediately overlain by a distinctive seismic facies showing wavy layering formed by one to maximal four seismic reflections with limited lateral continuity (Figures $6 \mathrm{~b}$ and $7 \mathrm{~d}$ ). These features form long-wavelength $(50-100 \mathrm{~m})$, low-amplitude $(<50 \mathrm{~cm})$ structures that can be observed throughout the entire upper basin. The resulting undulating upper surface of these features is smoothed out by few overlying reflections, so that the uppermost $\sim 3.5 \mathrm{~m}$ of seismic Unit B show the same parallel "layer cake" reflection pattern as the entire underlying $>55-\mathrm{m}$-thick sedimentary infill (Unit A; Figure $7 \mathrm{c}$ ).

[30] In order to sedimentologically characterize these seismically imaged wavy features, core ZHK04-5 was recovered through such a bed form (Figure 7d) and the correlative core interval was analyzed in detail. Figure 8 shows the compiled data of the target section. In both, core photo and $\mathrm{X}$ ray image, a clear $\sim 2$-cm-thick, light gray layer with a fine-sand base can be identified at $4.13 \mathrm{~m}$ below lake floor (mblf). It is characterized by an upward decrease in both bulk density and mean grain size and clearly shows a graded textural character. From its sedimentary facies, stratigraphic position and its high-impedance contrast compared to the surrounding sediment, as indicated by high bulk density and high $\mathrm{P}$ wave velocity values, this layer correlates to the high-amplitude reflection observed in the seismic data at $\sim 4 \mathrm{~m}$ depth (Figure $7 \mathrm{~d}$ ) that corresponds to the basin-wide mass movement event layer. Above this sand layer, no sedimentary features can be visually identified within the dark greenish-gray iron sulfide mud. Grain size analysis, however, reveal values of $\sim 30 \mu \mathrm{m}$ mean grain size within this specific interval indicating slightly coarser material than in the sediment above and below. Furthermore, grain size data suggest inverse grading within a small interval between 4.09 and 4.11 mblf. This interval is overlain by a $\sim 3-\mathrm{cm}$-thick succession that clearly shows a fining-upward trend. In this section, a $\sim 8^{\circ}$ inclining, faint high-density layering can be observed 


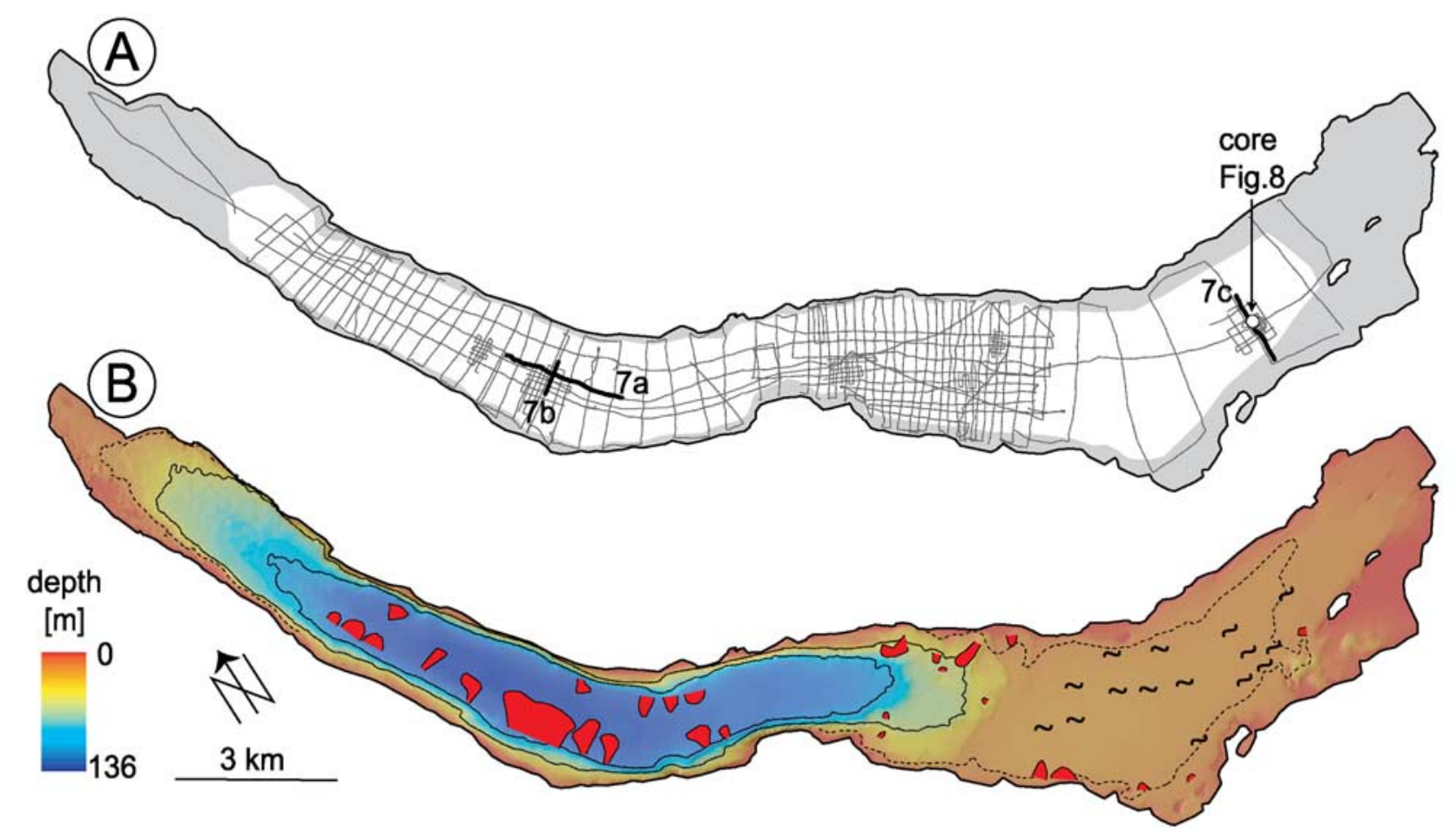

Figure 6. (a) The $3.5 \mathrm{kHz}$ seismic survey grid in Lake Zurich and location of profiles (solid black line) and core ZHK04-5 (open circle) shown in Figures 7 and 8. Gray-shaded areas indicate marginal areas where acoustic signals did not penetrate into the subsurface. (b) Distribution of coeval subaquatic landslide deposits (red areas) and bed form structures (squiggles) as mapped along the characteristic E layer in the seismic data from the lower and upper flat basin. Background shows colored bathymetry with 50-m contours intervals (black lines). Dotted line marks 20-m-depth contour line and aims to clarify basin morphology in the upper flat basin.

in the $\mathrm{X}$ ray image providing evidence for cross-bedding structures. From its stratigraphic position, this few $\mathrm{cm}$ thick succession characterized by a sequence of reversed and normal grading and cross-bedding, correlates to the observed wavy structures in the seismic data.

[31] Our seismic grid spacing of $\sim 50-100 \mathrm{~m}$ does not allow for 3-D spatial reconstruction of crest and trough orientations of these wavy structures, nor do 2-D seismic lines indicate any consistent symmetries or asymmetries. Nevertheless, these structures clearly appear to be longwavelength $(50-100 \mathrm{~m})$, low-amplitude $(<50 \mathrm{~cm})$ bed forms formed under flowing water conditions that only prevailed during a very short time period. Lacking higherresolution spatial information, reconstruction of flow direction and interpretation of formation processes remain inconclusive. Nonetheless, the occurrence of these conspicuous current-induced sedimentary structures immediately overlying the prominent basin-wide mass movement layer is unique within the entire sedimentary succession and suggests an exceptional event during the Late Pleistocene basin evolution.

\section{Discussion}

[32] Our data from the subsurface of Lake Zurich recorded the fingerprint of an outstanding event (E layer) affecting both the lower deep as well as the upper flat basin at $\sim 13,760$ calibrated years B.P. This E layer thus is a valuable candidate to be related to the proposed catastrophic drainage of the moraine-dammed Lake Zurich [Schindler, 1971]. In the following section we will first discuss the relationship between RM deposits and the proposed moraine breaches and then discuss arguments supporting that the observed bed forms in Lake Zurich can be related to the sudden lake drainage in the aftermath of the moraine dam failure. In the subsequent section we will dwell on possible causes and trigger mechanisms and place our findings in a more general context of natural hazards related to outbursts from moraine-dammed lakes.

\subsection{Zurich Moraine Dam Breaches}

[33] The sedimentary facies, reconstructed thickness and spatial distribution of the RM deposits downstream of the moraine suggests that these deposits are related to the four eroded zones of the moraine dam as indicated by thick lobes deposited below the breached dam (Figure 3). It further attests that the Sihl River, which temporarily discharged backward into Lake Zurich, could not have been the dominant eroding agent, because in this case, one would expect the erosion products to be deposited in the $\mathrm{S}$ of the moraine dam and not in the $\mathrm{N}$ of it, as observed. Therefore, the four gateways through the moraine must have been formed by erosion from outflowing Lake Zurich water prior to the period, during which the Sihl River discharged 

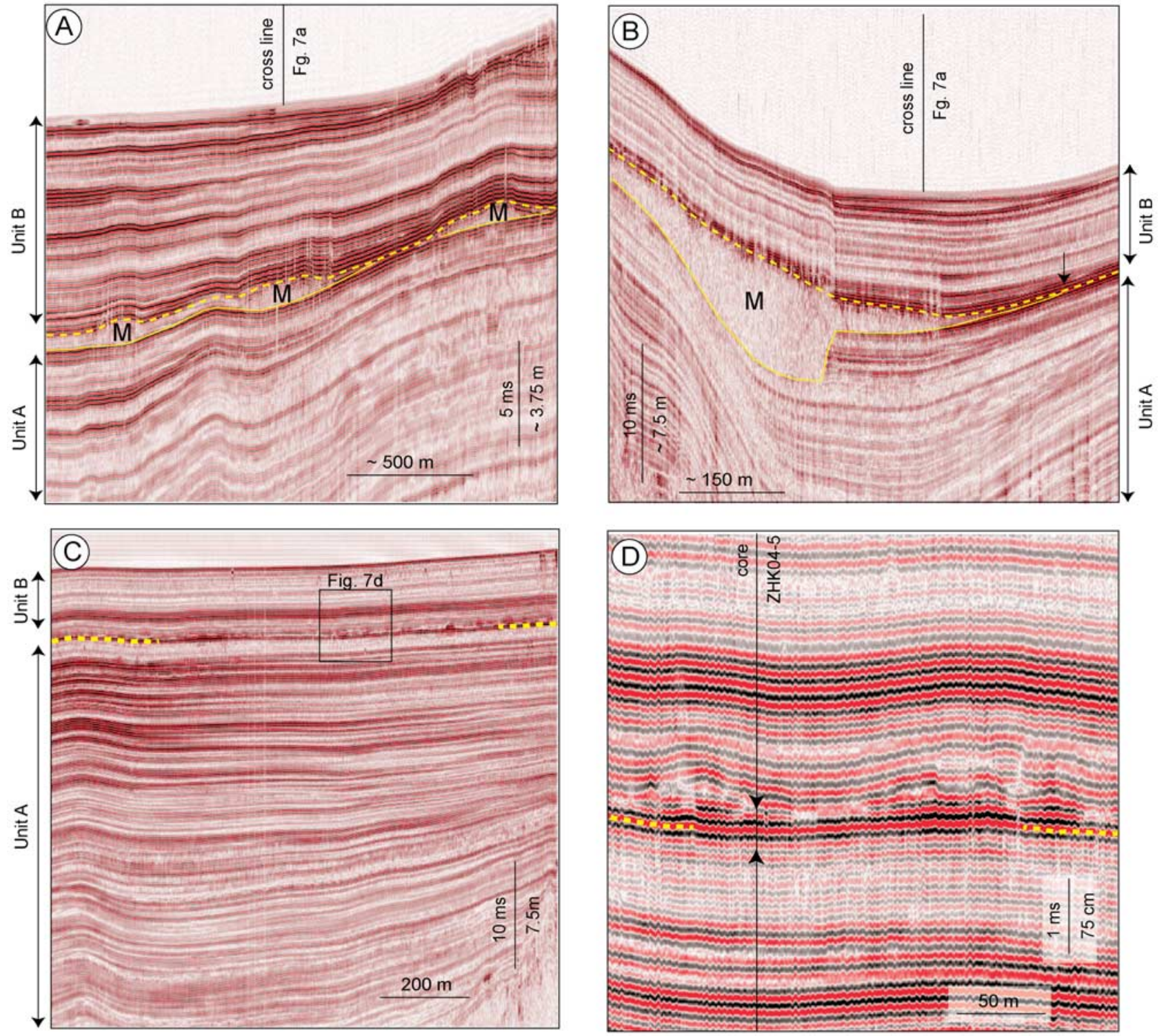

Figure 7. The $3.5 \mathrm{kHz}$ reflection seismic profiles (pinger source) showing the characteristic seismic features that occur along the E layer marked by yellow dashed lines. See Figure 6a for location of seismic lines. (a) Longitudinal profile along the lake axis in the lower deep basin showing three coeval mass movement deposits (M). (b) Perpendicular cross profile showing the distinct transparent seismic facies of one mass-flow deposit with well-defined lateral pinch out geometry (black arrow). (c) Seismic section showing the monotonous parallel-laminated reflection pattern in the sediment-filled upper basin. Rectangle shows approximate location of Figure 7d. (d) Close-up view of wavy seismic features immediately overlying the E layer in the upper basin. Vertical line gives the position of core ZHK04-5, and arrows indicate the core interval shown in Figure 8.

southward into the lake. The lack of quantitative information on the former moraine dam geometry and on the exact location of the lowest points on the initial dam does not allow to conclusively explaining number, location and occurrence of the four breaches. However, as these four gateways are all eroded down to the same topographic level, it is likely that breaching occurred in a single event, because one would expect that continuous erosion of the moraine rather results in one single Lake Zurich outlet channel, which, once started to incise, abandons the other outflow gateways because of lower base level in the incised outflow channel.

[34] The spatial depositional pattern of the RM deposits and its sedimentary facies with boulder-sized clasts in proximal areas and cobbles and pebbles also $>3 \mathrm{~km}$ downstream of the moraine, indicate very high energy transport conditions. Such conditions appear less likely to be related to continuous remobilization in successively eroding lake outlet channels, because an initial Lake Zurich outflow prior to the erosion of the dam may have had a topographic gradient of only $\sim 2-3^{\circ}$ (i.e., calculated from the $\sim 12 \mathrm{~m}$ 


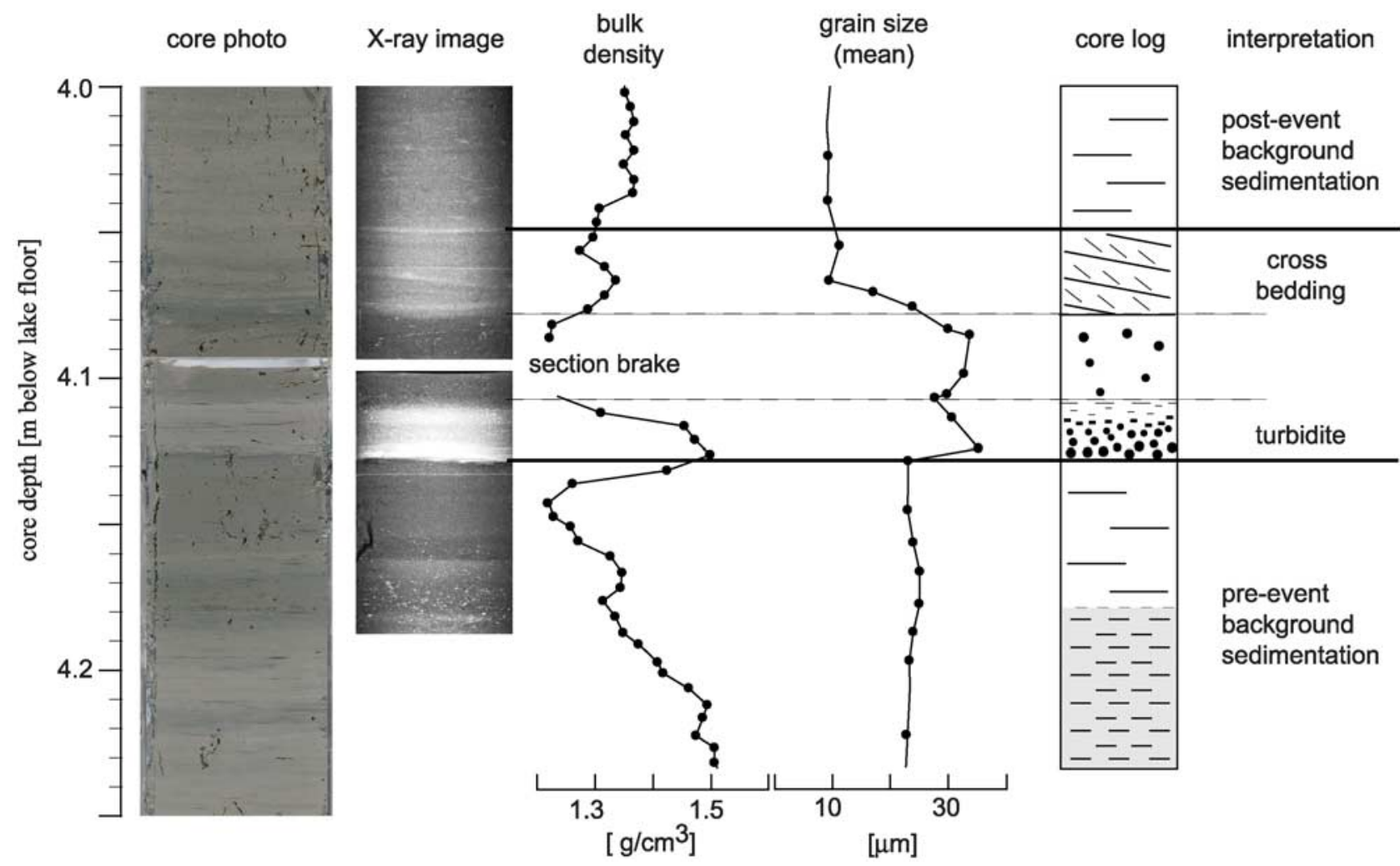

Figure 8. Compilation of sedimentological data and observations characterizing the $\mathrm{E}$ layer as cored in core ZHK04-5. See Figures $6 \mathrm{a}$ and $7 \mathrm{~d}$ for core location and depth position of shown interval, respectively. See legend in Figure 5 for lithological symbols used in the core log.

height difference between Lake Zurich and Schlieren Lake paleolake levels and reconstructed width of the moraine dam $(200-400 \mathrm{~m})$ ). Further information on erosion rates and processes comes from our results reconstructing the stratigraphic position of the RM facies relative to the lacustrine sediments of the Schlieren Lake and the alluvial gravel deposits of the Sihl and Limmat rivers. The two western lobes clearly overlie alluvial gravels assigned to the Sihl fan and thus indicate RM deposition after the Sihl River already filled in the western parts of the Schlieren Lake basin. There are no evidences in core logs that RM deposits interfinger with alluvial Sihl fan deposits, but they are described as a massive single unit. These observations point toward discrete remobilization within a short time long after the formation of the moraine dam. In the eastern moraineproximal area and also in more distal areas further downstream, RM deposits overlie Schlieren Lake sediments. The resulting boundary separating Sihl fan gravels in the $\mathrm{W}$ and Schlieren Lake deposits in the E as RM deposit substratum (black dashed line in Figure 3), is interpreted to correspond to the paleodelta front of the Sihl River within the Schlieren Lake during the time of RM deposition. Alternatively, it may mark the boundary of a $\sim 500$-m-wide and $\sim 20$-mdeep zone where an exceptional flood, potentially resulting from a lake outburst, was channelized incising into formerly deposited alluvial gravels and lacustrine deposits along a former river bed of the Limmat River (Figure 2b).

[35] Combining all arguments, our findings support Schindler's [1971] hypothesis of a sudden Zurich Moraine failure that consequently resulted in catastrophic drainage of Lake Zurich.

\subsection{Timing}

[36] In order to conclusively assign the $\mathrm{E}$ layer observed in Lake Zurich to the moraine dam failure and outburst event, an independent age control is required. The timing of the breaches can be relatively constrained by evaluating the stratigraphic position of Sihl delta deposits in Lake Zurich. The Sihl River temporarily discharged into Lake Zurich after the moraine was breached and the lake level was lowered, so that the partly emptied lake acted as the local base level for the Sihl River. Previous studies [Huber, 1938; Schindler, 1968, 1971, 1974, 1976] revealed that Sihl delta deposits are intercalated with lacustrine sediments of lithologic Unit 2 and the lower part of lithologic Unit 3. They are never associated with Unit 1 deposits. Thus, the stratigraphic position of the Sihl delta deposits provides a rough age estimate suggesting that the moraine breaches occurred immediately before the onset or during the deposition of lithologic Unit 2.

[37] This independent age estimate is within the same range as the date obtained for the outstanding $\mathrm{E}$ layer $(\sim 13,760$ calibrated years B.P.) that records a remarkable event of simultaneous basin-wide subaquatic landsliding and subsequent formation of peculiar current-induced bed forms in the upper flat basin. We therefore interpret these features to be the fingerprint of the moraine dam failure and subsequent lake outburst. 


\subsection{Lake Zurich Outburst}

[38] The peculiar bed forms in the upper flat basin suggest that they were formed under flow conditions that allowed for entrainment and transport of sediment particles. Also, the observed sedimentary succession in our core data showing a normally graded turbidite overlain by a sequence of reversed and normal grading with cross-bedding structures indicates peculiar transient sediment transport and flow conditions. The basal turbidite is interpreted to be related to the basin-wide mass movement event (see subsection 4.2.3). The overlying succession of reversed and normal grading may be interpreted as the sedimentary deposits following a hyperpycnal flow [e.g., Mulder et al., 2003]. However, a hyperpycnal flow alone may not fully explain the occurrence of cross-bedding structures and the high-wavelength, low-amplitude bed forms throughout the upper flat basin. These structures are rather interpreted to have originated from water movements within the whole water column. We hypothesize that such hydrodynamic conditions may have been induced by far field drawdown effects related to the sudden lake drainage following the moraine-dam failure.

[39] In order to test this hypothesis, we quantitatively analyzed theoretical discharge scenarios induced by the lake outburst. By performing simple calculations of flow velocities and sediment transport threshold criteria, we evaluate, whether the modeled flow conditions allow for the formation of the observed bed forms. In this first-order approach, we assume that the formation of sedimentary structures is controlled by the capacity of the drainage-induced flow to entrain and transport particles along the bed of the upper flat basin. In cohesive fine-grained material the sediment transport capacity can be approximately evaluated by quantitatively comparing the shear velocity $\left(u^{*}\right)$ of a flow, which tends to move particles, and the grain settling velocity $(w)$, which counteracts movement [e.g., Middleton and Southard, 1984]. The critical threshold condition for full suspension then is given as $w=u^{*}$ and we can formulate that our hypothesis is a reasonable scenario if

$$
w<u^{*}
$$

with Stokes'law

$$
w=1 / 18 * D^{2} \gamma^{\prime} / \mu
$$

and Logarithmic velocity law

$$
u^{*}=u /\left[(1 / k) \ln \left(y / y_{o}\right)\right]
$$

where $D$ is the grain size, $\gamma^{\prime}$ is the submerged specific weight (i.e., the difference between solid grain and water density times gravitational acceleration), $\mu$ is the water viscosity (equal to $0.001567 \mathrm{~kg} \mathrm{~s}^{-1} \mathrm{~m}^{-1}$ at $4^{\circ} \mathrm{C}$ ), $u$ is the flow velocity (i.e., discharge volume divided by the crosssectional area divided by time), $k$ is Von Karman's constant (equal to a value about 0.4 in clear flows), $y$ is the flow depth, and $y_{o}$ is the roughness length (equal to a value of about $1 / 30$ of the mean grain size $D$ [Allen, 1997]).

[40] To calculate the settling velocity we used a mean grain size of $30 \pm 2.5 \mu \mathrm{m}$ as measured in core ZHK04-5, and a solid grain density of $2.71 \pm 0.02 \mathrm{~g} \mathrm{~cm}^{-3}$ [Giovanoli, 1979]. To calculate the shear velocity, we first have to estimate the discharge volume, paleowater depth, and duration of the outflow. Standard GIS software is able to reconstruct the surface area of the paleolake prior to the lake-level fall using reconstructions in the Linthplain and Walensee area [Müller, 1995; Schindler, 2004] and extrapolating the paleolake level to $\sim 417$ masl in a digital elevation model (DEM) after correction for differential surface uplift between Lake Zurich and Walensee over the last $\sim 14,000$ years (estimated to be in the order of $\sim 7 \mathrm{~m}$ [Kahle et al., 1997]). This reconstructed outline of the paleolake (Figure 1) has an area of $\sim 210 \pm 10 \mathrm{~km}^{2}$ (uncertainties are mainly due to slight discrepancies in the different paleolake outline reconstructions in the eastern part). Assuming a lake-level drop of $\sim 12 \pm 2 \mathrm{~m}$ (i.e., difference between reconstructed paleolake level and lake level at the beginning of Sihl delta sedimentation in Lake Zurich) the outburst drainage volume then is estimated to be $\sim 2.5 \pm 0.5 \mathrm{~km}^{3}$. Note that this estimate does not account for the different slope geometries along the shoreline, which may add another, but negligible small error $(<1 \%)$. Water depth at the sites of observed bed forms were reconstructed on the basis of paleobathymetry reconstructions from the seismic data that recorded the sedimentary structures today at a depth of $\sim 24 \pm 2 \mathrm{~m}$ below lake level corresponding to a paleowater depth of $\sim 36 \pm 4 \mathrm{~m}$. The discharge cross section was defined perpendicular to the E-W trending axis of the upper Lake Zurich basin because flow directions induced because of far field drawdown effects of the lake outburst must have been oriented in an axis-parallel fashion. As a representative discharge cross section we calculated an area through the location of site ZHK04-5 using paleobathymetry reconstructions and DEM data. There, the discharge cross section is $\sim 1.06 \pm 0.06 \mathrm{~km}^{2}$ (uncertainties mainly due to inaccurate knowledge of paleoshore line position and value of slope inclinations).

[41] Having constrained estimates of all input parameters and their uncertainties (Table 2), the shear velocity now mainly depends on the unknown duration of the flow. Our hypothesis can now be tested by plotting $w / u^{*}$ as function of different outflow durations (Figure 9), for which the criterion $w / u^{*}=1$ can be used as the critical threshold for the formation of the bed forms. The results of our calculations show that particle entrainment and thus the potential to form the observed bed form structures can be related to Lake Zurich outburst scenarios if the reconstructed outflow volume of $\sim 2.5 \pm 0.5 \mathrm{~km}^{3}$ drains within maximal 12 days (range of uncertainties $\sim 7-19$ days) or faster (Figure 9).

[42] Assuming a most conservative scenario of draining the whole drainage volume $\mathrm{V}$ within the maximal duration of 12 days at constant discharge rates, estimated minimal discharge values would be $\sim 2400 \mathrm{~m}^{3} \mathrm{~s}^{-1}$ (range of uncertainties $\sim 1200-5000 \mathrm{~m}^{3} \mathrm{~s}^{-1}$ ). However, effective peak discharge values may have been significantly higher because the lake outflow may not have lasted as long as the estimated maximal duration. Also, the assumption of constant discharge rates over the entire drainage duration represents a simplified assumption because discharge is likely to have decreased significantly as the lake level dropped. Furthermore, reconstructions considering drainage volume and duration of outflow alone do not account for the 
Table 2. Parameters Used for Flow Calculations

\begin{tabular}{lccl}
\hline \multicolumn{1}{c}{ Input Parameter } & Mean Value & Range of Uncertainty & \multicolumn{1}{c}{ References } \\
\hline Grain size $D[\mu \mathrm{m}]$ & 30 & $27.5-32.5$ & this study \\
Discharge volume $V\left[\mathrm{~km}^{3}\right]$ & 2.5 & $2-3$ & this study \\
Cross-sectional area $A\left[\mathrm{~km}^{2}\right]$ & 1.06 & $1-1.12$ & this study \\
Flow depth $y[\mathrm{~m}]$ & 36 & $32-40$ & this study \\
Solid grain density $\rho_{\mathrm{s}}\left[\mathrm{g} / \mathrm{cm}^{3}\right]$ & 2.71 & $2.69-2.73$ & Giovanoli $[1979]$ \\
Karman's constant $k$ dimensionless & 0.4 & $\ldots$ & Allen $[1997]$ \\
Roughness length $y_{0}[\mu \mathrm{m}]$ & $1 / 30 D$ & $\ldots$ & Allen $[1997]$ \\
Water density $\rho w\left[\mathrm{~g} / \mathrm{cm}^{3}\right]$ & 1 & $\ldots$ & at $4^{\circ} \mathrm{C}$ \\
Water viscosity $\mu\left[\mathrm{g} \mathrm{s}^{-1} \mathrm{~m}^{-1}\right]$ & 1.567 & $\ldots$ & at $4^{\circ} \mathrm{C}$ \\
Gravitational acceleration $g\left[\mathrm{~m} / \mathrm{s}^{2}\right]$ & 9.81 & $\ldots$ & $\ldots$ \\
\hline
\end{tabular}

complex physical, hydraulic and hydrological processes involved in flowing water through the moraine breaches. Walder and O'Conner [1997] argue that for large outbursts (where the volume of the lake is large relative to the lake level drop as in the Lake Zurich situation) the volume does not exert primary control on peak discharge and maximum values rather are controlled by critical flow conditions defined by the breach geometry and amplitude of lake level drop.

[43] In order to obtain a first-order estimate of potential maximal magnitude of the Lake Zurich outburst we here use a simple, empirically calibrated model-based equation assuming rectangular breach geometry as proposed by Fread [1996]

$$
Q_{p}^{\prime}=3 H^{\prime} W^{\prime}\left(H^{\prime}\right)^{0.5}
$$

where $Q_{p}^{\prime}$ is peak discharge, and $H^{\prime}$ and $W^{\prime}$ are the breach height and width, respectively (note that the equation uses non-SI units; $Q_{p}^{\prime}$ is given in cubic feet per second with $1 \mathrm{~m}^{3}$ $\mathrm{s}^{-1}=35.3147 \mathrm{ft}^{3} \mathrm{~s}^{-1}$, and $H^{\prime}$ and $W^{\prime}$ are given in feet with $1 \mathrm{~m}=3.2808 \mathrm{ft}$ ). Using representative mean values as inferred from our study (i.e., $H^{\prime}=$ lake level drop $=12 \pm 2 \mathrm{~m}$ and $W^{\prime}=$ mean width of the four breaches $=300 \pm 100 \mathrm{~m}$ ) peak discharge values for the Lake Zurich outburst are estimated to $\sim 20,600 \mathrm{~m}^{3} \mathrm{~s}^{-1}$ (range of uncertainties $\sim 10,500-34,700 \mathrm{~m}^{3} \mathrm{~s}^{-1}$ ).

[44] These results provide a first-order estimate on the potential magnitude of the Lake Zurich outburst event and can be compared to published studies of catastrophic drainages of moraine-dammed lakes that occurred during historic times [Costa and Schuster, 1988; Clague and Evans, 2000, and references therein]. Although most of the reported historic events are mostly smaller in terms of discharge volume and thus also in terms of outflow duration, they are in a comparable order of magnitude related to peak discharge rates $\left(\sim 10^{3}-10^{4} \mathrm{~m}^{3} \mathrm{~s}^{-1}\right)$. Our simple approach thus supports the interpretation that a moraine breach triggered sudden drainage of Lake Zurich induced a current flow in the lake that was strong enough to form the observed sediment structures. Furthermore, the high estimated peak discharge values are in agreement with our interpretation that the RM deposits downstream the Zurich Moraine were transported under high-energy conditions.

\subsection{Trigger Mechanism of the Moraine Dam Failure}

[45] The E layer associated with the moraine dam failure and subsequent catastrophic drainage of Lake Zurich com- prises a series of sublacustrine landslides and turbidite deposits that have been recorded throughout the Lake Zurich basin. In core ZHK04-5 retrieved in the upper flat basin, the 2-cm-thick turbidite assigned to the basin-wide mass movement event stratigraphically underlies the current-induced sediment structures (Figure 8). This observation suggests that landsliding and remobilization of sediment from the slopes predates the occurrence of strong currents induced by the lake drainage. Therefore, we interpret that landsliding was not caused as a consequence of the lake level drop (e.g., shore collapses due to the lake level lowering along freshly emerged water-saturated lake deposits). This is in line with observations from the lower Lake Zurich basin, where seismic data along the slopes show

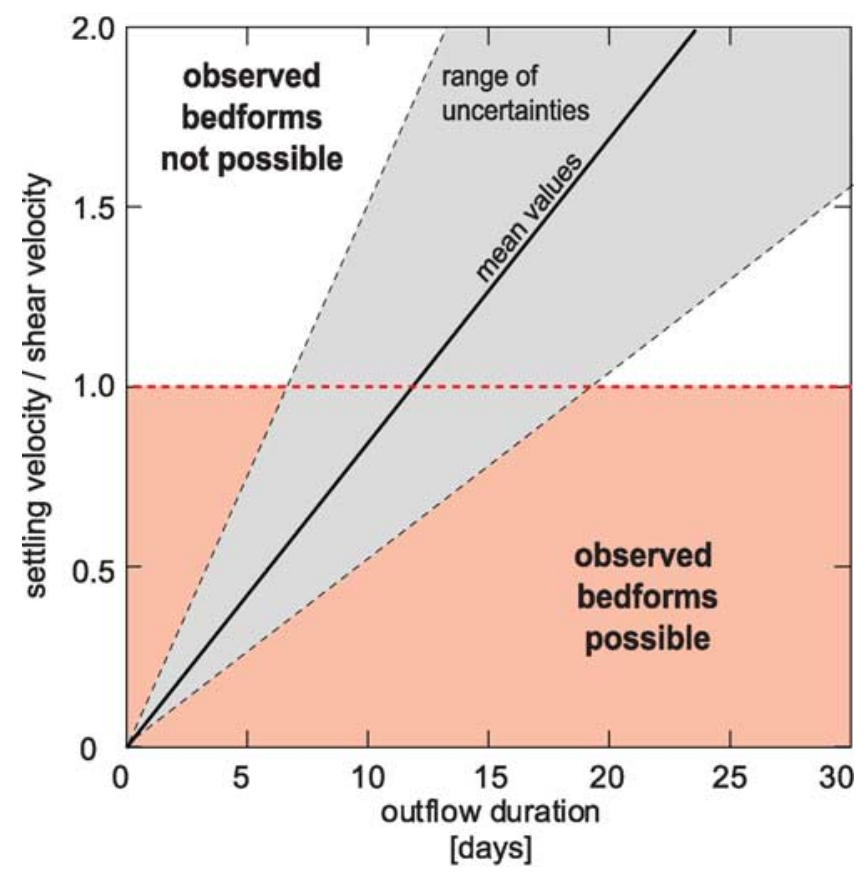

Figure 9. Results from calculations evaluating hydrodynamic conditions for different Lake Zurich outburst scenarios (i.e., time of outflow duration) in order to test whether the observed sedimentary structures in the upper flat basin can reasonably be related to the proposed sudden drainage event. We used a threshold criteria (marked as red dashed line), where settling velocity $(w)$ equals shear velocity $\left(u^{*}\right)$ (see section 5.3). Bold line indicates solutions with reconstructed mean values (Table 2), and gray area marks range of uncertainties. 
landslide scars in $>30 \mathrm{~m}$ water depth. Furthermore, none of the cored mass-flow deposits contains sediments pointing toward remobilization of shore material. Therefore, our data suggest that basin-wide landsliding resulted from sublacustrine slope failures that are related to a process that eventually initiated the catastrophic lake drainage.

[46] It has been reported in many studies that synchronous subaquatic landslide and turbidite deposits can be related to earthquakes that triggered slope failures on a regional scale [e.g., Shilts and Clague, 1992; Schnellmann et al., 2002; Goldfinger et al., 2003]. Strasser et al. [2006] showed that the discussed E layer characterized by 23 individual slides in Lake Zurich is the oldest of three events, during which earthquake shaking led to multiple sliding along the slopes of Lake Zurich. In fact, by temporal and spatial correlation of multiple subaquatic landslide deposits in Lake Zurich and Lake Lucerne, Strasser et al. [2006] reconstructed the occurrence of three major northern alpine earthquakes $(M>6.5)$ that hit the area of central Switzerland, with one of them occurring around $\sim 13,770 \pm$ 70 calibrated years B.P. Hence, we interpret that the moraine-dam failure and subsequent Lake Zurich outburst is related to this large northern alpine earthquake.

[47] It remains unknown, however, whether the primary effects of strong ground motions during the earthquake directly triggered the moraine dam to fail [e.g., Newmark, 1965]. We further consider the possibility that the earthquake-induced subaquatic landslides have the potential to trigger tsunamis in the lake that may eventually overtop the moraine and initiate incision into the moraine dam. It has been shown that lacustrine landslides that failed during a $M$ $\sim 6.2$ earthquake in 1601 A.D. triggered up to 4-m-high tsunami in Lake Lucerne [Schnellmann et al., 2002]. Considering that the Lake Lucerne landslides are comparable in terms of volume, slope angle and mode of failure initiation to the landslides observed in Lake Zurich [Strasser et al., 2007; Strasser and Anselmetti, 2008], the potential of landslide-triggered wave generation in Lake Zurich has to be taken into account. Furthermore, the earthquake may also have triggered rockfalls and landslides in the eastern part of the paleolake (e.g., Planggen-Klöntal rockslide [Schindler, 2004]; Figure 1) and/or instabilities along the steep slopes of today's Walensee) that might have caused impulse waves and thus could have contributed to wave generation.

[48] Our findings imply that the Zurich Moraine dam was stable over several thousands of years before it eventually failed $\sim 13,760$ calibrated years B.P. We therefore interpret that the internal moraine structure and geometry generally provided favorable moraine dam stability conditions. From a climatic perspective, the Zurich Moraine breach occurred during the Bølling stage, a time period that represents the onset of mid-European climatic amelioration after the end of the LGM [e.g., Denton et al., 2005]. Interstitial ice and permafrost within the moraine dam could potentially have sustained prior to climatic warming and added to the moraine stability for several thousand of years. Ice and/or permafrost thawing in the core of the moraine as well as increasing amount of water discharge from rapidly melting alpine glaciers in the catchment area of Lake Zurich during climate warming at the beginning of the Bølling stage then may have contributed to decreasing moraine stability conditions.

[49] Given that our findings suggest four simultaneously breached zones, ice core melting or piping as the ultimate trigger is anticipated to be unlikely because it would rather result in one single breach, as has been often reported from historic events [Costa and Schuster, 1988; Clague and Evans, 2000, and references therein]. This therefore supports our interpretation that a strong northern alpine earthquake was the critical process to eventually cause the moraine to fail at $\sim 13,760$ calibrated years B.P. The breach was either triggered by primary seismic ground shaking or by secondary earthquake effects such as subaquatic landslide-generated tsunami or rockslide-generated impulse waves, which might have overtopped the moraine dam and initiated failure and subsequent lake outburst.

\section{Summary and Conclusion}

[50] Results from our comprehensive case study in the Zurich area (central Switzerland) provide several independent evidences for the occurrence of a Late Pleistocene ( $\sim 13,760$ calibrated years B.P.) moraine dam failure and subsequent Lake Zurich outburst, and thus confirm and refine the Lake Zurich outburst - hypothesis proposed by Schindler [1971]. Our geophysical, sedimentological and geomorphological data combined with fluid dynamic calculations reveal a first-order lower-limit estimate on averaged outburst discharge (exceeding minimum values of $\sim 2400 \mathrm{~m}^{3} \mathrm{~s}^{-1}$ ) as well as a estimate on the potential maximal magnitude of the outburst event (peak discharge values $\sim 20,600 \mathrm{~m}^{3} \mathrm{~s}^{-1}$ ). We conclude that the catastrophic drainage of Lake Zurich was initiated after the moraine dam failed as a consequence of a strong northern alpine earthquake due to either primary earthquake shaking or secondary effects, such as overtopping by landslide-generated waves. Long-term causes, i.e., destabilization due to potential ice and/or permafrost thawing in the core of the moraine, as well as increasing amount of water discharge from rapidly melting glaciers in the catchment during a phase of climate warming, may have partially contributed to enhance the susceptibility of failure initiation prior to the occurrence of the eventual earthquake trigger.

[51] In general, our findings reveal that moraines damming lakes can be stable over several thousands of years, but also that stability conditions may decrease during periods of climate warming and that failure can be initiated suddenly during a strong seismic shaking event. To assess long-term future hazard scenarios resulting from lake outbursts, especially in the context of present-day climatic warming and rapid glacier retreat, during which the formation rate of potentially hazardous moraine-dammed lakes is increasing, the interplay of neotectonic activities and climate change thus needs to be considered. Both factors, together with moraine-specific internal strength characteristics (e.g., width-to-height ratio, material properties and consolidation stage [cf. Clague and Evans, 2000]) define threshold stabilities of natural dams and control occurrence and timing of hazardous future lake outburst.

[52] Acknowledgments. We thank Robert Hofmann as well as the whole ETH Limnogeology team and friends for technical support and 
assistance during the lake campaigns. Many thanks also to Urs Gerber for the core photographs. Dr. Ruedi Baumann and Andy Müller are acknowledged for helping to acquire X ray images. We thank Theo Kempf, Beat Rick, Christian Schlüchter, and Philip Allen for helpful discussions on data and interpretations and Andy Weller for English proofreading. Comments and suggestions of Oliver Korup, Guillaume St. Onge, and one anonymous reviewer significantly improved and completed the manuscript and are kindly acknowledged. Unpublished data was kindly provided by geoconsulting companies Jäckli Geologie AG, Geo Von Moos AG, and Sieber \& Cassina. This study was supported by the Swiss National Science Foundation (grant 620-066113).

\section{References}

Allen, P. A. (1997), Earth Surface Processes, 404 pp., Blackwell Sci., Oxford, UK

Blass, A., F. S. Anselmetti, and D. Ariztegui (2003), 60 years of glaciolacustrine sedimentation in Steinsee (Sustenpass, Switzerland) compared with historic events and instrumental meteorological data, Eclogae Geol. Helv., 96, 59-71.

Broecker, W. S. (2006), Was the younger dryas triggered by a flood?, Science, 312, 1146-1148, doi:10.1126/science.1123253.

Carter, D. T., L. L. Ely, J. E. O'Conner, and C. R. Fenton (2006), Late Pleistocene outburst flooding from pluvial Lake Alvord into the Owyhee River, Oregon, Geomorphology, 75, 346-367, doi:10.1016/j.geomorph.2005.07.023.

Clague, J. J., and S. G. Evans (2000), A review of catastrophic drainage of moraine-dammed lakes in British Columbia, Quat. Sci. Rev., 19, $1763-$ 1783, doi:10.1016/S0277-3791(00)00090-1.

Clarke, G. K. C., D. W. Leverington, J. T. Teller, and A. S. Dyke (2004), Paleohydraulics of the last outburst flood from glacial Lake Agassiz and the 8200 BP cold event, Quat. Sci. Rev., 23, 389-407, doi:10.1016/ j.quascirev.2003.06.004.

Costa, J. E., and R. L. Schuster (1988), The formation and failure of natural dams, Geol. Soc. Am. Bull., 100, 1054-1068, doi:10.1130/ 0016-7606(1988)100<1054:TFAFON $>2.3 . \mathrm{CO} ; 2$.

Denton, G. H., R. B. Alley, G. C. Comer, and W. S. Broecker (2005), The role of seasonality in abrupt climate change, Quat. Sci. Rev., 24, 11591182, doi:10.1016/j.quascirev.2004.12.002.

Eberli, G. P. (1984), Water content and bulk density of Zübo sediments, in Quaternary Geology of Lake Zurich: An Interdisciplinary Investigation by Deep-Lake Drilling, edited by K. J. Hsü and K. R. Kelts, pp. 115124, Schweizerbart, Stuttgart, Germany.

Furger, G. (1991), Von der geologie zum stofftransportmodell, Ph.D. thesis, 178 pp., Eidg. Tech. Hochsch. Zurich, Zurich, Switzerland.

Fread, D. L. (1996), Dam-breach floods, in Hydrology of Disasters: Water Scinece and Technology Library, vol. 24, edited by V. P. Singh, pp. 85126, Kluwer Acad., Dordrecht, Netherlands.

Giovanoli, F. (1979), Die remanente magnetisierung von seesedimenten, Ph.D. thesis, 200 pp., Eidg. Tech. Hochsch. Zurich, Zurich, Switzerland. Goldfinger, C., C. H. Nelson, and J. E. Johnson (2003), Holocene earthquake records from the Cascadia subduction zone and northern San Andreas fault based on precise dating of offshore turbidites, Annu. Rev. Earth Planet. Sci., 31, 555-577, doi:10.1146/annurev. earth.31.100901.141246.

Hampton, M. A., H. J. Lee, and J. Locat (1996), Submarine Landslides, Rev. Geophys., 34(1), 33-59.

Hsü, K. J., and K. R. Kelts (1970), Seismic investigation of Lake Zurich: part II: Geology, Eclogae Geol. Helv., 63, 525-538.

Hsü, K. J., and K. R. Kelts (1984), Quaternary Geology of Lake Zurich an Interdisciplinary Investigation by Deep-Lake Drilling, 210 pp., Schweizerbart, Stuttgart, Germany.

Huber, R. (1938), Der Schuttkegel der Sihl im Gebiete der Stadt Zurich und das prähistorische delta am see, Vierteljahresschr. Naturforsch. Ges. Zuerich, 83, 131-214.

Huggel, C., A. Kääb, W. Haeberli, P. Teysseire, and F. Paul (2002), Remote sensing based assessment of hazards from glacier lake outbursts: A case study in the Swiss Alps, Can. Geotech. J., 39, 316-330, doi:10.1139/ T01-099.

Huggel, C., W. Haeberli, A. Kääb, D. Bieri, and S. Richardson (2004), An assessment procedure for glacial hazards in the Swiss Alps, Can. Geotech. J., 41, 1068-1083, doi:10.1139/T04-053.

Jäckli, H. (1989), Geologie von Zurich, 215 pp., Orell Füssli, Zurich, Switzerland.

Kahle, H. G., et al. (1997), Recent crustal movements, geoid, and density distribution: Contribution from integrated satellite and terrestrial measurements, in Deep Structure of the Swiss Alps: Results of NRP 20, edited by O. A. Pfiffner et al., pp. 251-259, Birkhäuser Verlag, Basel, Switzerland

Kelts, K. (1978), Geological and Sedimentary Evolution of Lake Zurich and Zug, Switzerland, Ph.D. thesis, 224 pp., Eidg. Tech. Hochsch. Zurich, Zurich, Switzerland.
Kelts, K., U. Briegel, K. Ghilardi, and K. J. Hsü (1986), The limnogeologyETH coring system, Swiss J. Hydrol., 48, 104-115.

Kempf, T., and U. Walter (1985), Wärmegewinnung aus dem grundwasser im infiltrationsbereich der Limmat in Zuerich, Wasser Energ. Luft, 77, $343-350$.

Kempf, T., M. Freimoser, P. Haldimann, V. Longo, E. Müller, C. Schindler, G. Styger, and L. Wyssling (1986), Die Grundwasser Vorkommen im Kanton Zurich, 211 pp., Schweiz. Geotech. Kom., Bern.

Lister, G. S. (1985), Late Pleistoncene alpine degalciation and post-glacial climatic Developments in Switzerland: The record from sediments in a peri-alpine lake basin, Ph.D. thesis, 151 pp., Eidg. Tech. Hochsch. Zurich, Zurich, Switzerland.

Lister, G. S. (1988), A 15,000-year isotopic record from Lake Zuerich of deglaciation and climatic change in Switzerland, Quat. Res., 29, 129141, doi:10.1016/0033-5894(88)90056-7.

Magny, M. (2004), Holocene climate variability as reflected by midEuropean lake-level fluctuations and its probable impact on prehistoric human settlements, Quat. Int., 113, 65-79, doi:10.1016/S1040-6182(03)00080-6.

Malde, H. E. (1968), The catastrophic late Pleistocene Bonneville flood in the Snake River plain, Idaho, U.S. Geol. Surv. Prof. Pap., 596, 52.

Middleton, G. V., and J. B. Southard (1984), Mechanic of Sediment Movement, 401 pp., Soc. of Sediment. Geol., Tulsa, Okla.

Mulder, T., J. P. M. Syvitski, S. Migeon, J.-C. Faugeres, and B. Savoye (2003), Marine hyperpycnal flows: Initiation, behavior, and related deposits: A review, Mar. Pet. Geol., 20, 861-882.

Müller, B. U. (1995), Das Walensee-Seeztal: Eine typusregion alpiner talgenese von entstehung und vergehen des grossen Rheintal/Zurichsee, Ph.D. thesis, 226 pp., Univ. Bern, Bern.

Newmark, N. M. (1965), Effects of earthquakes on dams and embankments, Geotechnique, 15, 139-160.

O’Connor, J. E., and V. R. Baker (1992), Magnitudes and implications of peak discharges from glacial Lake Missoula, Geol. Soc. Am. Bull., 104, 267-279, doi:10.1130/0016-7606(1992)104<0267:MAIOPD>2.3.CO;2.

O'Connor, J. E., and J. E. Costa (1993), Geologic and hydrologic hazards in glacierized basins in North America resulting from 19th and 20th century global warming, Nat. Hazards, 8, 121-140, doi:10.1007/BF00605437.

Oerlemans, J. (2000), Holocene glacier fluctuations: Is the current rate of retreat exceptional?, Ann. Glaciol., 31, 39-44.

Penk, A., and E. Brückner (1909), Die Alpen im Eiszeitalter, Tauchnitz, Leipzig, Germany.

Pika, J. (1983), Zur Isotopengeochemie und Mineralogie der lacustrinen Ablagerungen im Zurichsee und im Schwarzen Meer, Ph.D. thesis, 232 pp., Eidg. Tech. Hochsch. Zurich, Zurich, Switezerland.

Reimer, P. J., et al. (2004), IntCal04 terrestrial radiocarbon age calibration, $0-26$ cal kyr BP, Radiocarbon, 46, 1029-1058.

Reynolds, J. M. (1992), The identification and mitigation of glacier-related hazards: Examples from the Cordillera Blanca, Peru, in Geohazards, edited by G. J. H. McCall et al., pp. 143-157, Chapman and Hall, London.

Riesen, K., and F. Naef (2007), What can Neolithic and Bronze Age lake dwellings tell us about former climate change?, paper presented at General Assembly 2007, Eur. Geophys. Union, Vienna, 15-20 April.

Rudoy, A. N. (2002), Glacier-dammed lakes and geological work of glacial superfloods in the Late Pleistocene, southern Siberia, Altai Mountains, Quat. Int., 87, 119-140, doi:10.1016/S1040-6182(01)00066-0.

Schindler, C. (1968), Zur Quartaergeologie zwischen dem untersten Zuerichsee und baden, Eclogae Geol. Helv., 61, 395-433.

Schindler, C. (1971), Geologie von Zurich und ihre beziehung zu seespiegelschwankungen, Vierteljahresschr. Naturforsch. Ges. Zuerich, 116, $285-315$.

Schindler, C. (1974), Zur geologie des Zuerichsees, Eclogae Geol. Helv, 67, $163-196$.

Schindler, C. (1976), Eine geologische karte des Zuerichsees und ihre deutung, Eclogae Geol. Helv., 69, 125-138.

Schindler, C. (2004), Zum Quartär des Linthgebietes Zwischen Luchsingen, dem Walensee, und dem Zuricher Obersee, Landesgeologie/Bundesanst. Fur Wasser und Geol., Bern-Ittingen, Switzerland.

Schlüchter, C., and C. Röthlisberger (1995), 100,000 jahr gletschergeschicht, in Gletscher im Ständigen Wandel, edited by Schweizerische Akademie der Naturwissenschaften, pp. 47-64, vdf Hochschulverlag AG, Zurich, Switzerland.

Schneider, J.-L., N. Pollet, E. Chapron, M. Wessels, and P. Wassmer (2004), Signature of Rhine Valley sturzstrom dam failures in Holocene sediments of Lake Constance, Germany, Sediment. Geol., 169, 75-91, doi:10.1016/ j.sedgeo.2004.04.007.

Schnellmann, M., F. S. Anselmetti, D. Giardini, J. A. McKenzie, and S. N. Ward (2002), Prehistoric earthquake history revealed by lacustrine slump deposits, Geology, 30, 1131-1134, doi:10.1130/00917613(2002)030<1131:PEHRBL > 2.0.CO;2. 
Schnellmann, M., F. S. Anselmetti, J. A. McKenzie, and D. Giardini (2006), 15,000 years of mass-movement history in Lake Lucerne: Implications for seismic and tsunami hazards, Eclogae Geol. Helv., 99, 409-428, doi:10.1007/s00015-006-1196-7.

Shilts, W. W., and J. J. Clague (1992), Documentation of earthquake-induced disturbance of lake-sediments using subbottom acoustic profiling, Can. J. Earth Sci., 29, 1018-1042.

Sidler, C. (1988), Signification de la palynologie appliquée aux sédiments détritique et organiogène du Pléistocène supérieur: Eam-terdiglaciaire vürmien et de l'Holocène entre Zoug, Zurich, et Baden (Suisse), Ph.D. thesis, 218 pp., L'Ecole Polytech. Féd. Zurich, Zurich, Switzerland.

Smith, D. G., and T. G. Fisher (1993), Glacial Lake Agassiz: The northwestern outlet and paleoflood, Geology, 21, 9-12, doi:10.1130/00917613(1993)021<0009:GLATNO>2.3.CO;2.

Strasser, M., and F. S. Anselmetti (2008), Mass-movement event stratigraphy in Lake Zurich; A record of varying seismic and environmental impacts, Beiträge zur Geologie der Schweiz, Geotech. Ser., vol. 95, pp. 23-41, Schweiz. Geotech. Kom., Zurich, Switzerland, in press.

Strasser, M., F. S. Anselmetti, D. Fäh, D. Giardini, and M. Schnellmann (2006), Magnitudes and source areas of large prehistoric northern Alpine earthquakes revealed by slope failures in lakes, Geology, 34, 1005-1008, doi:10.1130/G22784A.1.
Strasser, M., S. Stegmann, F. Bussmann, F. S. Anselmetti, B. Rick, and A. Kopf (2007), Quantifying subaqueous slope stability during seismic shaking: Lake Lucerne as model for ocean margins, Mar. Geol., 240, 77-97, doi:10.1016/j.margeo.2007.02.016.

Teller, J. T., and L. H. Thorleifson (1983), Glacial Lake Agassiz, in Glacial Lake Agassiz, edited by J. T. Teller and L. Clayton, pp. 261-290, Geol. Assoc. of Can., St. John's, Newfoundland.

von Moos, A. (1942), Zur Quartärgeologie von Hurden-Rapperswil (Zurichsee), Eclogae Geol. Helv., 36, 32-54.

Walder, J. S., and J. E. O'Connor (1997), Methods for predicting peak discharge of floods caused by failure of natural and constructed earthen dams, Water Resour. Res., 33(10), 2337-2348.

Watanabe, T., and D. Rothacher (1996), The 1994 Lugge Tsho glacial lake outburst flood, Bhutan Himalaya, Mt. Res. Dev., 16, 77-81.

F. S. Anselmetti, Sedimentology Group, Department of Surface Waters, Swiss Federal Instiute of Aquatic Science and Technology, Überlandstrasse 133, P.O. Box 611, CH-8600 Dübendorf, Switzerland.

C. Schindler, Schwerzestrasse 7, CH-8618 Oetwil am See, Switzerland. M. Strasser, Research Center Ocean Margins, University of Bremen, Marum Building, Leobener Strasse, Room 1220, D-28359 Bremen, Germany. (mstrasser@uni-bremen.de) 